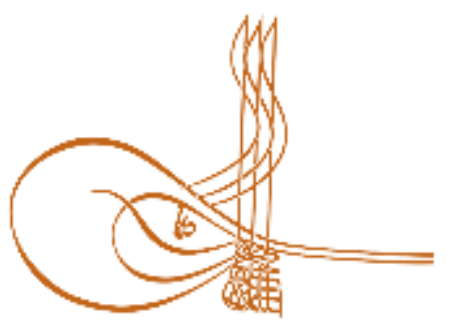

www.turkishstudies.net/turkishstudies
Turkish Studies

eISSN: $1308-2140$

Research Article / Araştırma Makalesi

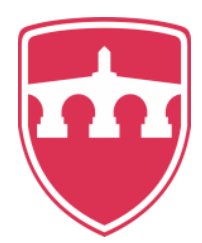

INTERNATIONAL

BALKAN

UNIVERSITY

Sponsored by IBU

\title{
Anneler Günü ve Babalar Günü Reklamlarında Toplumsal Cinsiyet İnşası
}

\author{
Gender Bulding in Mother's Day's and Father's Day's Advertisements
}

\author{
Duygu Ünalan* - Elif Şeşen**
}

\begin{abstract}
An advertisement aims to create new necessity, values and life style, tries to show the aspects of a person, product or service which will please the indiviuals. While doing this, it benefits from images, indications and also cultural and social pre-acceptance. As a discourse, positioning in advertising is not done independently of product and culture. Because human makes sense of everything including advertisement messages according to social association; however this sense-making is not fixed and changes over time. Media reconstructs consumption patterns and life styles aimed at female and male through various tools. Advertisements repeats social stereotypes via traditional values and settled ideas related to gender. Among the discourses of the advertisements prepared for Mother's Day and Father's Day, there are various differences, especially advertised products. On the Mother's Day, the advertisements of the products such as white goods and small home appliances which are directed their traditional roles and emphasizes social positions; on the other hand, on the Father's Day, the products from car to tie which are used by men directly are advertized. Through these advertisements, discourses which reflect gender's roles are reconstructed. This study aims to analysis gender construction in TV advertisements which were prepared for Mother's Day and Father's Day and were featured on TV channels before these days for the year of 2018 through semiotic analysis. In the study, a general evaluation of the reflections of gender construction in advertisements was made and the advertisements were examined around repeated common themes about motherhood and fatherhood. With the classification of the advertisements under common themes, in Mother's Day advertisements "Mother gives confidence", "Mother is compassionate", "Mother is sacrifice" themes; in Father's Day advertisements, the themes of "Father is related but authoritarian", "Father is strong, he does not show his feelings" and "Father is sacrifice" themes emerged. Looking at the advertisements examined in the study, it is seen that the gender roles attributed to men and women in society are repeated. In advertisements, the mother (woman) is described as loving, reassuring, self-sacrificing and compassionate; father (man) is a person who does not show his emotionality, is strong and provides a living for the house. While in the advertisements examined, there is no emphasis on the business life of the mother in the advertisements of the Mother's Day, while in the Father's Day advertisements, the father is seen as the employee. The analysis of the advertisements revealed that the
\end{abstract}

* Dr. Öğr., Üyesi, Niğde Ömer Halisdemir Üniversitesi, İletişim Fakültesi, Gazetecilik Bölümü Asst. Prof. Dr., Nigde Omer Halisdemir University, Faculty of Communication, Department of Journalism ORCID 0000-0002-7420-2006 duyguunalan85@gmail.com

*** Doç. Dr., Niğde Ömer Halisdemir Üniversitesi, İletişim Fakültesi, Halkla İlişkiler ve Reklamc1lık Bölümü Assoc. Prof. Dr. Nigde Omer Halisdemir University, Faculty of Communication, Department of Journalism ORCID 0000-0002-8513-9647

elifsesen@gmail.com

Cite as/ Atıf: Ünalan, D., Şeşen, E. (2020). Anneler günü ve babalar günü reklamlarında toplumsal cinsiyet inşası, Turkish Studies, 15(2), 1453-1481. https://dx.doi.org/10.29228/TurkishStudies.41769

Received/Geliş: 14 February/Şubat 2020

Accepted/Kabul: 25 April/Nisan 2020

Checked by plagiarism software

Copyright (C) MDE, Turkey 
gender roles attributed to the mother and father in the society are repeated in the advertisements of mother's day and father's day, and that these roles are re-established through the advertisements.

Structured Abstract: Today, the advertisements that create a mythical and natural ideological atmosphere with the cultural and social pre-acceptance that it leaned beyond the aim of product promotion; by entering desires, values, consumption patterns and lifestyles it enters almost every aspect of our daily life. Advertisements that we watch unconsciously, mostly without questioning, thinking too much, have become the source and transmitter of sexist prejudice and pre-acceptance by repeating the traditional roles given to men and women. Gender representations in television commercials are like a reflection of gender inequality.

Gender is mainly used to explain that femininity and masculinity cannot be defined by reference only to biological differences, and to show and emphasize the differences constructed by the sociocultural values resulting from biological differences. The social construction of gender also affects the social meaning of motherhood and fatherhood, which is one of the roles and characteristics associated with gender. Motherhood discourse established in advertisements is often constructed with sacrifice and meticulousness, and paternity discourse with power and security. The consumption patterns of men and women, which are popularized by the advertisements, are transferred to us through tools such as symbols, gestures, slogans and idioms.

In this study, which aims to keep a semiotic mirror on the construction of gender in Mother's Day and Father's Day ads, the messages conveyed in the establishment of gender in the advertisements broadcasted on national television channels in 2018 before these two special days were analyzed. A total of 21 ads related to Mother's Day and 14 ads related to Father's Day were examined. With the classification of the advertisements under common themes, in Mother's Day advertisements "Mother gives confidence", "Mother is compassionate", "Mother is sacrifice" themes; in Father's Day advertisements, the themes of "Father is related but authoritarian", "Father is strong, he does not show his feelings" and "Father is sacrifice" themes emerged.

Gender determines the position of women and men in society. These positions have been adopted by a large part of the society. While the woman is given the role of being more emotional, patient, resourceful, soft-headed, loving; what is expected from the man is to be brave and harsh, to listen to his word, to act with his mind, not with his emotions. What is expected from a woman for her "good" motherhood is her loyalty and devotion to her husband and children. What is expected of "good" paternity of men is to work outside and earn a lot to meet the financial needs of the family. In other words, gender role patterns fit women inside the house and men outside the house. Because even if the woman is working, domestic responsibilities such as cooking and cleaning are her duties.

Looking at the advertisements examined in the study, it is seen that the gender roles attributed to men and women in society are repeated. In advertisements, the mother (woman) is described as loving, reassuring, self-sacrificing and compassionate; father (man) is a person who does not show his emotionality, is strong and provides a living for the house. While in the advertisements examined, there is no emphasis on the business life of the mother in the advertisements of the Mother's Day, while in the Father's Day advertisements, the father is seen as the employee.

In advertisements, the mother is always seen inside the house, while the father is working outside. Even if the mother works, she is seen as the person who does the work of the house time out of work. In the advertisements that underline the sacrifice of both mother and father, the sacrifice of the mother is expressed as giving up her own desires and wishes for the well-being of her children (For example, the mother who cannot drink tea for her children in Çaykur ad). The sacrifice of the fathers, on the other hand, has been fulfilling their children's wishes without resting, despite the fact that they are tired from work (For example, the father who comes from work in Maximum ad takes his children to travel without rest).

It is possible to see that the gender roles of the parents are reflected in the advertisements in terms of the gifts received for the parents. While buying a small household appliance and a flower for the mother; for the father, the seat is taken for personal use. Therefore, gift indicatives refer to the social role of the mother and father.

In society, fathers are not usually / traditionally concerned with the care of children, this task belongs to the mother. Fathers do not spend individual time with their children, do not play with them, they are usually parents who are emotionally distant. However, in the advertisements examined, it is seen that this role attributed 
to the father is tried to be broken. Fathers are positioned as individuals who take care of their children, show their love for them and spend quality time with their children.

Generally speaking, the gender roles attributed to the mother and father in the society are repeated in the advertisements of mother's day and father's day, and therefore, these roles have been re-established.

One of the main limitations of the study is that the method is not sufficient and suitable for making a deep and comprehensive comment on the causes and results of the difference between the advertisements. It will also be useful to work with different methods to understand the perspective of advertisers and the effect of advertisements on viewers.

Keywords: Advertisement, television, gender, Mother's Day, Father's Day

Öz: Yeni ihtiyaçlar, değerler ve yaşam tarzları yaratmayı amaçlayan reklam; kişi, ürün ya da hizmetlerin bireylerin hoşuna gidecek özelliklerini öne çıkarmaya çalışır. Bunu yaparken de imge ve göstergeler ile kültürel ve toplumsal ön kabullerden faydalanır. Bir söylem olarak reklamda konumlandırma üründen ve kültürden bağımsız bir şekilde yapılmaz. Çünkü insan, reklam mesajları da dahil her şeyi kültürel ve toplumsal çağrışımlarına göre anlamlandırır fakat bu anlamlandırma sabit değildir, zamanla değişir. Medya erkek ve kadına yönelik tüketim kalıplarını ve yaşam tarzlarını çeşitli araçlarla yeniden kurar. Reklamlar toplumsal cinsiyete dair geleneksel değer ve yerleşik düşünceler ile toplumsal stereotipleri tekrar eder. Anneler günü ile babalar günü için hazırlanan reklamların söylemleri arasında başta reklamı yapılan ürünler olmak üzere çeşitli farklılıklar dikkati çeker. Anneler gününde daha çok kadınların geleneksel rollerini ve toplumsal konumlandırılmalarını vurgulayan beyaz eşya ya da küçük ev aletleri gibi ürünlerin reklamları öne çıkarken babalar gününde arabadan kravata daha çok doğrudan erkeğin kullanacağı ürünlerin reklamları yapılır. Bu reklamlar ile kadın ve erkeğe biçilmiş toplumsal cinsiyet rollerini yansıtan söylemler yeniden inşa edilir. Bu çalışma, Anneler Günü ve Babalar Gününe özel olarak hazırlanan ve bu günlerin hemen öncesinde Türk televizyon kanallarında 2018 yılında yayınlanan TV reklamlarındaki toplumsal cinsiyet inşasını göstergebilimsel yöntemden hareketle çözümlemeyi amaçlamaktadır. Çalışmada toplumsal cinsiyet inşasının reklamlardaki yansımalarının genel bir değerlendirmesi yapılmış olup reklamlar, anneliğe ve babalığa dair tekrarlanan ortak temalar etrafında incelenmiştir. Bu bağlamda Anneler Günü reklamlarında "Anne güven verir", "Anne şefkatlidir", "Anne fedakârdır" olmak üzere üç tane, Babalar Günü reklamlarında "Baba ilgili ama otoriterdir", "Baba güçlüdür, duygularını belli etmez" ve "Baba fedakârdır" olmak üzere üç tane tema üzerinde uzlaşılmıştır. Reklamlarda anne(kadın) sevgi dolu, güven veren, fedakâr, şefkatli olarak betimlenirken; baba (erkek) duygusallığını belli etmeyen, güçlü, evin geçimini sağlayan kişidir. İncelenen reklamlarda Anneler Günü reklamlarında annenin iş hayatına dair vurgu yapılmazken, Babalar Günü reklamlarında baba çalışan kişi olarak görülmektedir. Reklamların analizi toplumda anne ve babaya atfedilen toplumsal cinsiyet rollerinin anneler günü ve babalar günü reklamlarında tekrarlandığını, söz konusu rollerin reklamlar aracılığıyla yeniden kurulduğunu ortaya koymuştur.

Anahtar Kelimeler: Reklam, televizyon, toplumsal cinsiyet, Anneler Günü, Babalar Günü

\section{Giriş}

Günümüzde ürün tanıtımı amacını aşarak yaslandığ 1 kültürel ve toplumsal ön kabuller ile mitsel ve doğal bir ideolojik atmosfer yaratan reklamlar; arzular, değerler, tüketim kalıpları ve yaşam tarzları inşa ederek gündelik hayatımızın hemen her alanına sirayet etmektedir. Çoğunlukla sorgulamadan, fazla düşünmeden, bilinçsizce izlediğimiz reklamlar, kadına ve erkeğe biçilen geleneksel rolleri tekrarlayarak cinsiyetçi önyargı ve ön kabullerin yeniden üreticisi ve aktarıcısı haline gelmiştir. Televizyon reklamlarındaki cinsiyet temsilleri toplumsal cinsiyet eşitsizliğinin bir yansıması gibidir.

Toplumsal cinsiyet temel olarak kadınlık ve erkekliğin sadece biyolojik farklılıklara referansla tanımlanamayacağını anlatmak, biyolojik farklılıkların neticesinde ortaya çıkan sosyokültürel değerlerin inşa ettiği farklılıkları göstermek ve vurgulamak için kullanılmaktadır. Cinsiyet ile toplumsal cinsiyet arasındaki fark, kadın ya da erkek olmanın biyolojik olduğu kadar 
sosyolojik olarak da anlamına dayanmaktadır ve bu farkın en açık ve yoğun şekilde görülebildiği mecraların başında reklamlar gelmektedir. Kadınlar daha çok temizlik ve mutfak ürünlerinin reklamlarında; erkekler araba, banka, elektronik cihaz gibi ürünlerin reklamlarında yer alır. Reklamlarda cazibeli, hamarat ya da süper kadın; aktif, maceracı, iktidar sahibi erkek stereotipi sunulur. Mutlulukla evini temizleyen, eşinin ya da çocuklarının ihtiyaçlarını karşılayan kadın tipine ya da ofiste çalışan, toplantı yapan erkek tipine sıkça yer verilir. Reklamlar, yazılı ya da görsel göstergeler üzerinden toplumsal dokuya sinmiş cinsiyetçi rol kalıplarının izleyici ile konuştuğu birer metin, birer söylemdir. Reklamların içerdiği göstergeler çözümlenerek insan ve topluma dair pek çok bilgiye ulaşılabilir.

Cinsiyetin toplumsal inşası, cinsiyetle bağlantılı rol ve özelliklerin başında yer alan annelik ve babalığın toplumsal anlamını da etkiler. Reklamlarda kurulan annelik söylemi sıklıkla fedakârlık ve titizlikle, babalık söylemi ise güç ve güvenlikle kurgulanır. Reklamlar tarafından yaygınlaştırılan kadın ve erkeğe dair tüketim kalıpları semboller, jestler, sloganlar, deyimler gibi araçlarla bize aktarilır.

Toplumsal cinsiyetin inşasını çözümlemeye yönelik bir girişim, aslında erkekliğin ve kadınlığın çok katmanlı sosyolojik yapısını çözümlemeye, ev içinde ve dışında kadın ve erkek olmanın her türlü gündelik faaliyetimizin içine nasıl işlemiş olduğunu anlamaya yönelik bir çabadır. $\mathrm{Bu}$ çalışma, Anneler Günü ve Babalar Günü reklamlarında toplumsal cinsiyetin inşasına göstergebilimsel bir ayna tutmayı amaçlamaktadır. Çalışmada, 2018 yılında, Anneler Günü ve Babalar Günü’ne özel olarak hazırlanan ve bu iki özel gün öncesinde ulusal televizyon kanallarında yayınlanan reklamlardaki toplumsal cinsiyetin kuruluşunda aktarılan mesajlar çözümlemeye tabi tutulmaktadir.

\section{Toplumsal Cinsiyet}

İster kişiler arası ister grup içi ya da toplumsal iletişimde olsun bireylerin cinsiyet normları hakkında mesaj alma ve verme şekillerini anlamak, bireyi ve toplumu anlamak için önemlidir. İnsanların nasıl davranacaklarını ve etkileşimde bulunacaklarını belirlemede kullandıkları temel paradigma olması nedeniyle toplumsal cinsiyet, iletişim bilimleri başta olmak üzere sosyal bilimler alanında en çok çalışılan ve araştırılan konulardan biridir.

Biyolojik bir ayrımdan çok daha geniş anlamlar taşıyan toplumsal cinsiyet, sadece bireysel bir kimlik ifadesi değil aynı zamanda belirli bir cinse ait olma ya da olmamanın ne anlama geldiğini belirleyen bir dizi kural, norm ya da uygulamadır (Htun ve Weldon, 2018: 16). Bu bakımdan toplumsal cinsiyet atfedilmiş bir statü, toplumda bireye atfedilen bir konumdur. Kişinin biyolojik cinsiyetinin doğrudan bir sonucu olmayan toplumsal cinsiyet, bireyi kadın ya da erkek olarak işaret eden psikososyal özelliklere işaret eder ve pek çok günlük eylemde, yeniden üretilip kurgulanır (Giddens, 2012: 104). Toplumsal cinsiyet bir dereceye kadar biyolojik cinsiyetle ilişkilidir ancak kadınlar ve erkekler ile ilişkilendirilen statü, sorumluluk ve kişilik özellikleri biyolojik cinsiyetle doğrudan ilişkili değildir. Bunları biyolojik cinsiyeti temel alarak kadına ve erkeğe yükleyen aslında kültürdür (Günindi Ersöz, 2016: 20). Ridgeway (2011) cinsiyeti, diğer kimliklerle dolayımlanan davranışları etkileyen birincil bir kültürel çerçeve olarak görmektedir. Toplumsal cinsiyetteki 'cinsiyet' kavramı kadın ve erkeğe biçilen cinsiyet kalıplarına ve toplumun onlardan beklediği davranışlara işaret etmektedir (Bayhan, 2012: 148). Toplumsal cinsiyet, kadın veya erkek için toplumun uygun gördüğü doğal olmayan değer kalıplarına dikkati çeker.

Toplumsal cinsiyete dair kadınlık ve erkeklik kategorileri, kişilik özellikleri, davranış ve roller aslında sosyokültürel yapı dolayımıyla inşa edilmiş kategoriler olup toplumdan topluma ve zamandan zamana değişir (Nicholson, 1994). Cinsiyet başta olmak üzere yaşamımızdaki pek çok şeyle ilgili düşünme biçimimiz bizi çevreleyen kültürel gösterge ve imajların etkisi altındadır. Toplumsal değişime bağlı olarak değişen toplumsal cinsiyetin oluşumunda toplumsal örgütlenme tarzı belirleyici bir faktördür. Çünkü kadın ve erkek arasında doğal olduğu ileri sürülen birçok 
farklılık aslında toplumsal faktörler tarafindan belirlenmektedir. Cinsiyet farklarının varlığının doğal ve kaçınılmaz olduğunu düşündüğümüz için birçok başka toplumsal farkın da eşitsizlik yaratmasını normal karşılarız. Cinsiyet farkları toplumsal iktidar ilişkilerinin oluşumunda temel kurucu rol oynar. Bir yandan cinsiyetin doğuştan gelen bir biyolojik özellik olduğu düşünülür, diğer yandan kadınlara ve erkeklere ait cinsiyet özellikleri toplumsal davranış farkları olarak tanımlanır. Toplumsal değerler erkeksi ve kadınsı diye ayrışıp erkeksi olanlar değerli bulunur (Sancar, 2009: 28) ve otobüs şoförlüğünün neden erkeksi, sekreterliğin neden kadınsı bir meslek olarak görüldüğünü rasyonel bir sorgulama ile değil, ancak bu cinsiyet farklarının toplumsal işleyişini bilerek anlayabiliriz.

Cinsiyetin ve cinsiyet stereotiplerinin toplumsal inşası, "kadın" ve "erkek" ya da "eril" ve "dişil" olarak bilinen kavramsal kategorileri meşrulaştırma mekanizmasıdır ve toplumsal davranışları düzenler; bebeklerle oynayan kızlar ya da kadınlara evlenme teklif eden erkekler gibi bazı rol kalıplarını teşvik ederken elbise giymek isteyen veya yüksek sesle konuşan erkeklerin zorbalığa maruz kalması gibi bunlara uymayanlara dair yaptırımları da güçlendirir (Butler, 2004). $\mathrm{Bu}$ bakımdan kadınlık ve erkeklik toplumsal ve kültüreldir. Cinsiyet stereotipleri kadınları ve erkekleri farklılaştıran belirli inançlar olarak tanımlanabilir. Perkins'e (1997: 76) göre stereotip, yargısız sorgulama ve basitleşmiş bir yargıya yol açan kavramsal bir yapı olup kişilerin abartılı, genellikle negatif, karakter özelliklerine indirgenmesine işaret etmektedir. Deaux ve Lewis'e (1984: 992) göre kadın ve erkek cinsiyetine atfedilmiş kimi özelliklere dayandırılan cinsiyet stereotiplerinin; nitelik tanımlayıcıları (örneğin kendine güven, başkaları için endişe), fiziksel özellikler (örneğin saç uzunluğu, vücut ağırlığı), rol davranışları (örneğin liderlik, çocukların bakımı) ve mesleki durum (örneğin kamyon şoförü, ev hanımı) olmak üzere dört farklı bileşeni vardır.

Kadın ve erkeğin biyolojik farklılıkları, erkek egemen sistemde toplumsal cinsiyet stereotiplerinin ve rollerinin belirlenmesinde bir dayanak olarak kullanılmaktadır. Cinsiyete dayalı iş bölümü toplum tarafindan belirlenmekle birlikte biyoloji bu belirlenimin kaynağı ve önkoşuludur. Mevcut toplumsal yapıya sinmiş, toplumun büyük bir kısmı tarafından benimsenmiş, kadına ve erkeğe uygun görülen davranış biçimleri ve sorumluluklara işaret eden toplumsal cinsiyet, kadın ve erkeğin toplum içindeki konumunu da belirler. Kadının duygulu, sabırlı, becerikli, yumuşak başl1, sevgi dolu olması beklenirken erkeğin ise tersine cesur ve sert olması, sözünü dinletmesi, duyguları ile değil aklı ile hareket etmesi beklenir. Kadından "iyi" annelik için beklenen evine, eşine, çocuklarına bağlılık ve fedakarlıktır. Erkekten "iyi" babalık için beklenen ise ailenin maddi ihtiyaçlarını karşılamak için dışarıda çalışması ve çok kazanmasıdır. Bir başka deyişle toplumsal cinsiyete dair rol kalıpları kadına evin içini, erkeğe ise evin dışını uygun görür. Zira kadın çalışıyor olsa bile yemek ve temizlik gibi ev içi sorumluluklar yine onun görevidir. Crosby (1992: 133) göre toplumda var olan cinsiyet temelli iş bölümü erkekler için daha avantajlı konumlar sağlayan eşitsizlikler üretir.

\section{Toplumsal Cinsiyetin İnşasında Reklam Söylemi}

Kadına ve erkeğe atfedilen rolleri sergileyen toplumsal cinsiyete dair izleri özellikle geniş kitlelere seslenen ve aktaran medya mesajlarında bulmak mümkündür (Tosun, 2006: 89). Medya mesajları hem içinde üretildikleri toplumu yansıtır hem de bireylere toplumsal rollerine dair kodlar aktarır. Bireylerin toplumsal semboller, kurallar ve değerler aracılığıyla kendini ve kimliğini kurmasında medyanın rolü çok önemlidir. Kültürel ve toplumsal üretim sürecinin ayrılmaz bir parçası haline gelen medya, değer üretiminin yanı sıra bunların yayılmasına da aracılık eder. Medya toplumsal cinsiyetin kültüre bağlı farklı ve çelişkili tanımlarının çatışma, müzakere, uyum, üretim ve yeniden inşa alanıdır. Medyadaki cinsiyet stereotipleri, belirli gruplara kamuoyu onayı (veya statüsü) vermenin yanı sıra toplumsal olarak kabul edilmenin de yollarını yansitır (Carter ve Steiner, 2004: 2). Kadınlar ve erkekler medyada farklı özellikleri ön plana çıkarılarak temsil edilmekte, erkekler kariyer sahibi, para kazanan, yönetici olarak sunulurken kadınlar daha çok erkeklerin yardımcısı, para harcayan olarak gösterilmektedir (Macionis, 2013: 634). Medyada temsil edilen toplumsal 
cinsiyet rolleri, büyük oranda geleneksel değer, kod ve önyargıları yansıtmaktadır. Masallardan atasözlerine, oyunlardan şarkilara, filmlerden haberlere hemen hemen tüm televizyon programlarında da toplumsal cinsiyete dayanan tabakalaşma yeniden üretilir. Wood'a (2009: 275) göre medya metinlerinde erkekler daha güçlü, aktif, maceracı ve girişken olarak temsil edilirken kadınlar daha zayıf, ince, narin, genç, güzel, bağımlı, çekingen ve yetersiz olarak temsil edilir ki bunlar hâkim cinsiyetçi söylemlerdir. Baudrillard (1997) medya gerçekliğinde sunulan kadın ve erkek kimliklerinin biyolojik farklılıkların doğasından ziyade sistemin farklılaştırıcı mantığından kaynaklığına dikkati çekmektedir. Medya kadınlık ve erkeklik temsilleri ile toplumda kökleşmiş cinsiyet tanımları üzerinden bireylere çeşitli mesajlar vererek baskın toplumsal rol kalıplarının yerleşmesine aracılık eder. Sürekli olarak üretilen medya içerikleri ile toplumsal cinsiyetin ana hatları belirlenmiş olur (Toruk ve ark., 2013: 312).

Medya içerikleri içinde reklamlar, cinsiyetçi temsilleri yoğun olarak yansıtır. Medyanın sadece ekonomik değil kültürel yapısının temel taşı haline gelmiş reklam, insanların yaşamlarını etkileyen ve şekillendiren bir güce dönüşmüş durumdadır. Tüketim kalıplarından sosyokültürel değerlere gündelik hayatımızdaki her alana sirayet eden reklamlar; cinsiyetçi önyargı ve önkabullerin de inşa edildiği, sürdürüldüğü, aktarıldığı ve meşrulaştırıldığ erkeğe biçilen geleneksel rolleri tekrarlayan reklamlarda, kültürel ve toplumsal kodlara başvurulur. Sürekli tekrarlanan reklamlarla aktarılan toplumsal cinsiyete dair beklenen rol kalıpları bireylerin uygun görülen davranış biçimlerine dair düşüncelerini de etkiler (Stewart ve ark., 2002: 91). Reklamlardaki temsiller, kadın ve erkeğin doğal olarak farklı olduğu ön kabulüne dayanmakta ancak bu farklılı̆̆ın doğuştan gelen özelliklerden ziyade toplumsallaşma sürecinde kadına ve erkeğe biçilen davranış kalıpları üzerine inşa edilmekte olduğu fark edilmemektedir. Böylece reklamlar egemen cinsiyetçi söylemin sürdürülmesinde önemli bir mecra haline gelmektedir.

Reklamlar, cinsiyetlere özgü fantezilerin, mitlerin ve korkuların avantajlarından yararlanacak şekilde tasarlanır. Bu, reklamların toplumsal cinsiyet rollerini belirlediği anlamına gelmemekle birlikte belirli bir döneme egemen olan erkeklik ve kadınlık ile ilgili "geçerli kültürel değerleri" temsil ettiği şeklinde yorumlanabilir (Feasey, 2008: 139). Reklamlarda cinsiyet temsilleri ile ilgili araştırmaların yapılmasının temel nedeni, bu tür cinsiyet stereotipleştirmelerinin tüketicilerin inançlarını etkileyebileceğinin düşünülmesidir. Toplumsal cinsiyete bağlı değerler ile reklamlardaki toplumsal cinsiyet stereotipleri arasındaki ilişkinin doğası, uzun zamandır devam eden bir tartışmanın odak noktası olup "ayna" ve "yapı" olmak üzere iki karşıt argüman öne sürülmüştür (Eisend, 2010: 421). Ayna argümanının arkasında bir toplumun değer sistemini etkileyen çağdaş sosyoekonomik ve politik ortamda birbiriyle ilişkili birçok faktörün olduğu düşüncesi yatmaktadır. $\mathrm{Bu}$ nedenle reklamın etkisi önemsiz görünür. Bu bağlamda, reklamlarda yer alan kadın ve erkekler, genel olarak toplumsal cinsiyet rolleriyle ilgili baskın inançlara uyma eğilimindedir. Buna karşın "yapı" argümanı reklamların hedef kitlenin değerlerini etkilediğini ileri sürer ve reklamları toplumun ve kültürel değerlerinin bir yansıması olarak görür. Toplumsal gerçekliğin medya tarafindan şekillendirildiğini söyleyen bu yaklaşım medya temsillerinin imge ve kavramları kendi gerçekliğine uydurma eğiliminde olduğunu ileri sürer. Goffman'a (1987) göre, kadınları ve erkekleri etkileşimli olarak gösteren reklamlar, izleyiciyi geleneksel cinsiyet rolleri hakkında eğiten "cinsiyet göstergeleri” sunmaktadır. Stern'in (2003: 216) belirttiği gibi "reklamcılık, yerleşmiş eril ve dişil cinsiyet rollerinin yayılmasından sorumlu birincil araç" haline gelmiş olup başta cinsiyet kimlikleri olmak üzere toplumsal kimlikleri şekillendirerek izleyiciyi geleneksel cinsiyet rolleri hakkında eğitme işlevi görmektedir.

Toplumsal cinsiyetin reklamlardaki temsili ile ilgili 1970'lerde öncü niteliğindeki gazete ve dergiler üzerine yapılan çalışmalar (Courtney ve Lockeretz, 1971; Belkaoui ve Belkaoui, 1976) kadınların reklamlarda daha çok ev içindeki sorumlulukları bağlamında temsil edildiğini ortaya koyarken aradan geçen süre zarfinda çeşitli mecralarda yenilenen ve tekrarlanan çalışmalar (Whipple ve Courtney, 1985; Gilly, 1988; Bretl ve Cantor, 1988; Furnham ve Mak, 1999) da çok büyük bir 
değişimin yaşanmadığını göstermektedir. Reklamlarda kadın ve erkeğin temsiline dair karşılaştırmalı çalışmalar farklılığın, ürünler (örneğin teknolojik ürünlerde erkekler, ev içi ürünlerde kadınlar) ile sunum tarzında (örneğin uzman ya da karar verici olarak erkekler, ürünü kullanıcı olarak kadınlar) yoğunlaştığını göstermektedir (Cheng, 1997). Çeşitli çalışmaların sonuçları (Allan ve Coltrane, 1996; Craig, 1992; Ganahl ve ark., 2003; Lovdal, 1989; Kim ve Lowry, 2005; Paek ve ark., 2010; Uray ve Burnaz, 2003) ana karakterin cinsiyeti ile reklamı yapılan ürünün türü arasında anlamlı bir ilişki olduğunu göstermektedir. Erkekler ev dışı aktivitelerde ve bunlarla ilgili ürünlerin reklamlarında çok daha yoğun olarak gösterilmekte olup kadınlara ise aksi şekilde evde kullanılan ürünlerin reklamlarında yer verilmektedir (Coltrane ve Allan, 1994). Jha Dang ve Vohra'nın (2005) çalışması da kadınların ev ürünleri ve kişisel ya da güzellik ürünleri reklamlarında daha sık yer aldığını göstermiştir. Türkiye'de yapılan çalışmalar (Eziler Kıran, 2000; Özdemir, 2010; Yapar, 1999) da bu bulguları destekler niteliktedir. Örneğin Yılmaz'ın (2007) 1960-90 arasındaki 30 yıllık süreçte yazılı basındaki reklamlar üzerine yaptığı çalışma incelenen süre içindeki reklamlarda kadına atfedilen geleneksel rollerin ve geleneksel kadın imgesinin tekrar edildiğini göstermektedir. Reklamı yapılan ürünler ile kadının geleneksel toplumsal rolleri arasında bağ kurulmakta; evdeki temizlik ve mutfak işleri, çocukların dersleri ile iş yaşamındaki toplantıları aynı titizlikle yürüten ideal kadın tipi (Kuruoğlu ve Aydın, 2014: 59) sürekli tekrarlanmaktadır.

Televizyonun yaygınlığı ile izleyicilerin tutum ve algılarını etkileme potansiyeli dikkate alındığında televizyon reklamlarının toplumsal cinsiyet rollerindeki değişiklikleri yansıtmaktan uzak olmakla eleştirilmeleri daha önemli hale gelmektedir. Bugün televizyon, anlamın inşa edildiği bir temsil aracı; kültür olarak adlandırılan ve paylaşılan anlam ve değerlerin kurulduğu, dolaşıma sokulduğu ve yeniden üretildiği bir yer (Çelenk, 2005: 83) haline gelmiştir. Televizyon reklamlarındaki cinsiyet temsilleri mevcut toplumsal gerçekliği yansıtmadığı gibi klișeleșmiș cinsiyet imgelerini ekrana taşımaya devam etmektedir. ABD (Bretl ve Cantor, 1988; Wiles ve Tjernlund, 1991; Cheng, 1997), Danimarka (Furnham ve ark., 2000), Japonya (Sengupta, 1995; Furnham ve Imadzu, 2002), İngiltere (Furnham ve Skae, 1997) gibi çeşitli ülkelerde yapılan çalışmalar televizyon reklamlarında cinsiyete dair kalıpyargı ve klişelerin hala yaygın olduğunu göstermektedir. Türk televizyon reklamcılığındaki cinsiyet rolü temsillerini inceleyen Çağlı ve Durukan'ın (1989) çalışması kadınların ev ortamlarında daha fazla gösterildiğini ortaya koymuştur. Çankaya'nın (2013) çalışması da Türk televizyon reklamlarının geleneksel toplumsal cinsiyet temsil ideolojisini korumaya meyilli olduğunu göstermektedir.

\section{Anneler Günü ve Babalar Günü Reklamlarında Toplumsal Cinsiyet}

Anneler Günü ve Babalar Günü'ne özel reklamlar, toplumsal bilincin derinlerine işlemiş toplumsal cinsiyete dair ön kabullerin dışavurumu gibidir. Bu reklamlar ile kadın ve erkeğe biçilmiş toplumsal cinsiyet rollerini yansıtan söylemler büyük oranda yeniden inşa edilir. Bilindiği üzere her yıl mayıs ayının ikinci pazar günü kutlanan Anneler Günü, Amerikalı Anna Jarvis'in kendi annesi için ilk kez 1908 yılında düzenlediği anma günü ile başlamış, 1914 yılında ABD'de resmi olarak kabul edilmiştir (Jones, 1980: 175). Kısa bir sürede dünya genelinde yaygınlaşan Anneler Günü ülkemizde de 1950'lerden bu yana kutlanmaktadır. Yine ilk defa ABD'de kutlanan Babalar Günü fikri ise 1909 yılında Amerikalı Sonoro Smat Dodd adlı genç bir kadın tarafından ortaya atılmıştır. Her yıl haziran ayının üçüncü pazarı kutlanan Babalar Günü, Başkan Lyndon Johnson tarafindan 1966 y1lında resmi olarak kabul edilmiştir (Morman ve Floyd, 2006: 117). Ülkemizde Anneler Günü'nden daha sonra, 1980'li yıllarda kutlanmaya başlanmıştır. Birer anma günü olarak başlayan her iki günün de zamanla bir alışveriş çılgınlığına dönüşüp ticari taraflarının ön plana çıkmasıyla gerçek anlamlarını yitirmeye başladıkları söylenebilir.

Kadınlık ve erkeklik ile annelik ve babalığa dair toplumsal beklentilere yönelik bir bakış açısı sağlamak için Anneler Günü ve Babalar Günü ile ilgili kültürel göstergeleri analiz etmek için televizyon reklamları faydalı bir mecradır. Anneler Günü ile Babalar Günü için hazırlanan reklamlar 
arasında ürün, ortam, dil ve söylem düzeyinde çeşitli farklılıklar dikkati çeker. $\mathrm{Bu}$ farklılıklar arasında reklamı yapılan ürünler başta gelmektedir. Anneler gününde daha çok kadınların geleneksel rollerini ve toplumsal konumlandırılmalarını vurgulayan beyaz eşya ya da küçük ev aletleri gibi ürünlerin reklamları öne çıkarken babalar gününde takım elbiseden kravata daha çok erkeğin doğrudan kullanacağı ürünlerin reklamları yapılır. Anneye hediye edilmesi beklenen ürünler daha çok ev içi kullanıma hitap eden ve kadının annelik görevlerini daha iyi yapmasına yardımcı olan ürünlerdir. Buna karşın babaya hediye olarak düşünülen ürünlerse daha çok erkeğin bireysel kullanımı ve kişisel tatminine yöneliktir. Cote ve Deutsch'in (2008) bu günlerdeki hediyeler ile ilgili çalışması ABD'de annelerin aldıkları hediyelerin tipik olarak çiçek ve ailesiyle dışarıda akşam yemeği olduğunu, babaların hediyelerinin ise parfüm ve kravat başta olmak üzere sadece erkekler tarafından kullanılan ürünler olduğunu göstermektedir.

Cinsiyet gibi annelik ve babalık rolleri de toplumsal olarak inşa edilmektedir (Arendell, 2000; Marsiglio ve ark., 2000). Annelik toplumsal cinsiyetin tanımladığı ve biçimlendirdiği sosyokültürel bir kavram haline gelmiştir (Holmes, 2006: 2). Reklamlarda idealize edilerek sunulan anneliğin baskın teması yemek ve beslenme (Green, 2004) olup iyi bir annenin, çocuğun bakımı için zaman, emek ve duygu bakımından fedakâr (Shaw ve Lee, 2009), çocuğunun fiziksel ve duygusal ihtiyaçlarını karşılamak için kendini adamaya hazır olması gerektiği mesajı verilir (Warner, 2005). Johnston ve Swanson'un (2003) çalışması reklamlarda kadının özel alandaki annelik rolünün vurgulandığına dikkati çekerek annelerin çocuklarını besleyen, giydiren, onların ihtiyaçlarını karşılayan asıl kişi olarak temsil edildiklerini göstermektedir. Bunun gerisinde ise çocuk bakımının kadının doğal görevi olarak görülmesinin yattığı ifade edilmektedir. Reklamlarda iyi anneliğin para harcamaya ve daha fazla ürün satın almaya bağlandığı bir metalaşmaya da şahit olunmaktadır. Anneler satın aldıkları ürünler ile zorlu görevlerin üstesinden kolayca gelebilmekte ve böylece dışarıda çalışsalar bile kendilerini ailelerine adamış iyi eşler ve anneler olarak sergileme firsatı bulabilmektedirler (Brandes, 2017: 69). Kadın, anne olarak aile içindeki ilişkilerin de düzenlenmesi ve sürdürülmesinden sorumlu olarak resmedilirken erkek, baba olarak kamusal alandaki rolü ve başarısı ile gösterilir (West, 2009: 294). Prinsloo (2006: 138) reklamlarda babalık temsilinin sıklıkla 'iyi' bir babanın koruyucu ve eve ekmek getirmekten sorumlu kişi olarak kurulmasına dayandığını ifade etmektedir. Çocukların günlük bakımına katkıda bulunmayan baba, geleneksel erkeklik temsili ile uyumlu bir şekilde çocukların spor başta olmak üzere boş zaman aktivitelerinde öğretici ya da yol gösterici olarak sunulmaktadır (Coltrane ve Adams, 2008; LaRossa, 1997; Miller, 2011). Auster ve Auster-Gussman (2016) tarafindan Anneler ve Babalar Günü kutlama kartları üzerine yapılan çalışma sonuçları, babalara gönderilen kartlardaki mesajların 'iyi/harika baba' olmanın bir başarı göstergesi olarak kabul edildiğini gösterirken annelere yönelik kartlarda kişinin anne olarak başarısına dair mesaj veren bir kart olmadığı yönündedir. Reklamdaki ürünün bir kimlik, bir imaj sunduğu da dikkate alınırsa reklamlardaki mesajların mevcut kadınlık ve erkeklik ile annelik ve babalık rollerini yeniden üretmeye hizmet ettiği söylenebilir.

\section{Yöntem}

Bu çalışma, Anneler Günü ve Babalar Günü’ne özel olarak hazırlanan ve bu günlerin hemen öncesinde Türk televizyon kanallarında 2018 yılında yayınlanan reklamlardaki toplumsal cinsiyet inşasını göstergebilimsel yöntemden hareketle çözümlemeyi amaçlamaktadır.

Bir anlamlayımlar bilimi olan göstergebilim, anlamlı dizgeleri inceleyen insan bilimlerinin yöntemidir. Bir devinim ya da bir ses de gösterge olarak kabul edilebilir. İmgeler, kavramlar, düşünceler, görüşler gösterge dizgelerini oluşturur. Göstergebilim tüm gösterge ve simge dizgeleri ile anlamı inceler. Anlam nesneleriyle ilgilenen göstergebilim, iletişim bağlamlarını da bir anlam nesnesi, bir metin gibi ele alır. Göstergebilim, iletinin nasıl üretildiğini, aktarıldığını, yorumlandığını ya da çözümlendiğini inceler (Bourse ve Yücel, 2012: 181-183). Fiske’ye (2011: 122) göre göstergebilim, göstergelerin ve onların çalışma biçimlerinin araştırılmasıdır. Göstergebilime göre 
toplumsal olan her şey bir göstergedir ve var olmaya başladığ göstergesine dönüşmektedir. Gösterge (işaret) herhangi bir somut nesne, durum ya da kavramın yerine geçen ve onu işaret eden resim, yazı ya da görüntüdür (Dağtaş, 2013: 133). Göstergelere ve onların iletme biçimlerine olan ilgi ve merak Orta Çağa kadar dayanmaktadır. Ancak günümüz göstergebilimsel çözümlemenin öncüleri dilbilimci Ferdinand de Saussure ile Charles Saunders Pierce'dir (Geray, 2017: 172). Peirce, göstergebilimin mantıksal işlevini, Saussure ise toplumsal işlevini vurgulamaktadır. Modern anlamda göstergebilimsel çözümlemenin gelişmesinde ise Fransız felsefeci ve düşünür Roland Barthes'ın çalışmaları önemlidir (Sezer ve Yılmaz Sert, 2014: 24). Elbette bu üç isim dışında göstergebilimsel çözümleme üzerine çalışmış Umberto Eco, Algirdas Julien Greimas, Claude Levi-Strauss gibi pek çok önemli isim bulunmaktadır. Ancak bu çalışma Roland Barthes'ın göstergebilimsel çözümleme yöntemini temel almaktadır. Bu nedenle çalışmanın sinırlılıkları ve hacmi dolayısıyla yalnızca Barthes'ın göstergebilimsel çözümleme yönteminden bahsedilmiştir.

Barthes'ın göstergebilim kuramının merkezinde düz anlam ve yan anlam olmak üzere anlamlandırmanın iki düzeyi bulunmaktadır. Düz anlam, anlamlandırmanın ilk dizgesidir. Barthes'e (2016: 18) göre düz anlam, aslında ilk anlam değildir, ancak öyleşmiş gibi yapar. Düz anlam, aynı anda okumayı hem temellendiren hem de kapatır gibi görünen yan anlamların sonuncusudur. Yan anlam ise ikincil anlamdır. Yan anlamın göstereni, bir ilk göstergeden yani düz anlamdan oluşmaktadır. Yan anlamda onu kullananın duyguları, kültürel değerleri ön plana çıkmaktadır. Bu nedenle, yan anlamın öznel bir yapısı vardır ve ideolojik süreçleri kapsamaktadır. Mit ve çağrışım boyutlarına sahip olan yan anlamda; öznel duygular, düşünceler, sosyokültürel değerler yer almaktadır (Ataman Yengin, 2012: 15). Mitlerin temel işlevinin tarihi doğallaştırmak olduğunu söyleyen Barthes'e göre mitler, kendi kökenlerini, dolayısıyla siyasal ve toplumsal boyutlarını gizemleştirmekte ve gizlemektedirler. Örneğin; toplumda kadına annelik, ev kadınlı̆̆ rolleri biçilirken erkeğe ekmek parası kazanma rolü verilmektedir. Bu roller, "doğal" toplumsal yapıyı oluşturmaktadır. Mit bu anlamları doğanın bir parçası gibi sunarak tarihsel kökenlerini gizlemekte ve böylece bu anlamları evrenselleştirmektedir. Bunları yalnızca değişmez değil, adil bir biçimde hem erkeklerin hem de kadınların çıkarlarına hizmet eder görünmesini sağlamakta, böylece siyasal etkilerini de gizlemektedir (Fiske, 2011: 186-187).

Mit Çözümlemesi (Barthes, 2014: 184)

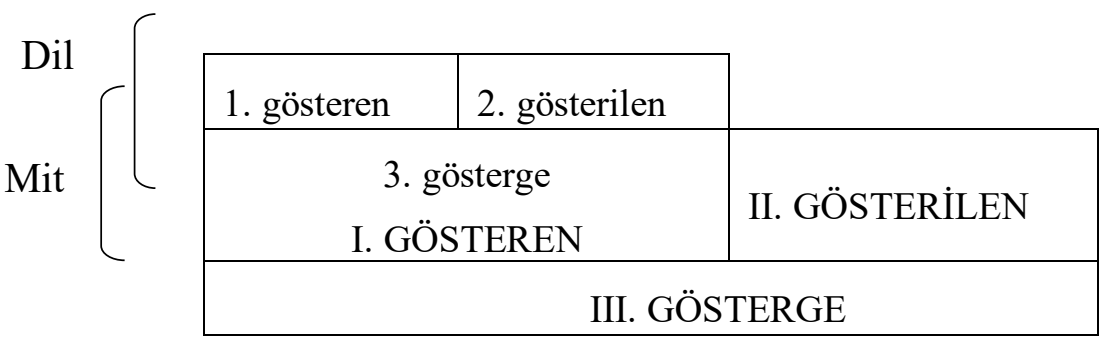

İkincil yani mitsel düzeyde, birincil yani dil düzeyinin göstergesi yeni bir gösterene dönüşerek mitin göstereni haline gelir. Reklam mitlerini göstergebilimsel açıdan değerlendiren Barthes'a (2014) göre, reklamlarda anlam görüntüsü, ilk anlam düzeyinde kodlanmamış ikonik bir görüntüdür. Yan anlam düzeyinde ise ikonik ya da simgesel bir görüntü vardır (Dyer, 2010: 182). Reklam söyleminde hem simgelerle düzgülenmiş kültürel iletiler hem de yazısal iletiler vardır. Hangi mecra için yapılmış olursa olsun reklamda söz işe karışmış demektir. Ancak reklamın sözü çoğunlukla gizli anlamlar taşır. Reklamın gösterdiği ürün onun düz anlamıdır, o ürünle kazanılacağı vaat edilen şey ise onun yan anlamıdır ve kendi içinde söylemsel bir bütünlük barındırmaktadır. Çözümleme sırasında bu gizli göstergelerin anlamları yorumlanmalıdır. Bir reklam iletisinin 
okunmasında içkin çağrışımsal bağıntılara sahip yan anlamsal bakış açısı, göstergelerin çeşitli ve zengin anlamlar taşıdığını ortaya koyabilmek için önemlidir (Çamdereli, 2006: 84-85).

Göstergebilimsel çözümlemenin temelinde, bir metnin ya da görüntünün ortada olan belirgin anlamını değil, onun arkasında yatan anlamını okuma davranışı bulunmaktadır (İmançer ve Özel, 1999: 8). Göstergebilimsel çözümlemenin odak noktası, yansız ve doğal olarak görünen; ancak gerçekte sistemleşmiş bir ideolojik sürecin bir parçası olan, kültürel pratiklerin içsel yapıları içindeki işaret sistemleridir (Alemdar ve Erdoğan, 1994: 270). Buradan hareketle bu çalışmada Anneler Günü ve Babalar Günü'ne özel televizyon reklamlarında kadınlık, erkeklik, annelik ve babalık kısaca toplumsal cinsiyetin sosyokültürel inşası göstergebilimsel çözümlemeye tabi tutulacaktır.

Nitel araştırmalarda amaç genelleme değil, bütüncül bir resim elde etmektir. Bu nedenle de olasılıklı olmayan, amaçlı örneklem alma yöntemleri nitel araştırmalarda sıkça kullanılan örneklem alma yöntemlerinden biridir. Amaçlı örneklem alma yöntemleri pek çok durumda, olgu ve olayların keşfedilmesi ve açıklanmasında yararlı olmaktadır (Yıldırım ve Şimşek, 1999: 136). Bu bağlamda çalışmada, amaca yönelik olarak amaçlı örneklem alınma yöntemine gidilmiş öncelikle bir medya takip ajansından 2018 yılında Anneler Günü ve Babalar Günü'nün üç gün öncesinde ulusal kanallarda (ATV, Fox TV, Kanal D, Show TV, Star TV, TRT 1) prime time (21.00-23.00 saatleri arası) saatlerindeki programlarda yayınlanan reklamların listesi alınmış, tekrarlar çıkarılmıştır. Toplam 423 reklam araştırmanın evrenini oluşturmaktadır. Anneler Günü'ne özel 21 reklam ile Babalar Günü’n özel 14 reklam olmak üzere toplam 35 reklam ise araştırmanın örneklemini oluşturmaktadır. Daha sonra video paylaşım kanalı Youtube'dan da reklam videolarına ulaşılmıştır. Çalışmada toplumsal cinsiyet inşasının reklamlardaki yansımalarının genel bir tablosunun çizilmesi hedeflenmiş olup reklamlar, anneliğe ve babalığa dair tekrarlanan ortak temalar etrafinda incelenmiştir. Tematik analiz, kodlama ve tema geliştirmeye odaklanmış analitik bir işlem ve bir veri kümesi içerisindeki kalıpları ya da temaları tanımlamak, çözümlemek ve raporlamak için kullanılan nitel bir yöntemdir (Lyons ve Rohleder, 2014: 96; Braun ve Clarke, 2006: 79). "Araştırma sorusuna bağlı olarak tüm verilerdeki temel fikri yakalayan ya da veri setindeki genel anlamı temsil eden bir şey" (Braun ve Clarke, 2006: 82) olarak tanımlanan temalar, sık kullanılan sözcükler, yinelenen faaliyetler, anlamlar ya da duygulara dair ifadelerden türetilmektedir ve temel olarak bir verinin ne ile ilgili olduğunu anlatmaktadırlar (Taylor ve Bogdan, 1989: 13; Saldana, 2009: 139). Analiz edilen nesne ya da konunun daha derin bir şekilde anlaşılmasını amaçlayan (Marks ve Yardley, 2004) tematik analiz, öncelikle temaların belirlenmesi ve analizin bu temalara göre yapılması (Fereday ve Muir-Cochrane, 2006) ya da öncelikle temel kategorilerin belirlenerek buna bağlı olarak temaların belirlenmesi (Simons, vd., 2008) şeklinde uygulanabilir. Bu çalışmada ikinci yöntem benimsenmiş olup öncelikle toplumsal cinsiyet üst kategori olarak belirlenmiş, daha sonra anneler günü ve babalar günü reklamlarında toplumsal cinsiyetin göstergesi olan alt temalar ortaya çıkarılmıştır. Bu bağlamda Anneler Günü reklamlarında "Anne güven verir", "Anne şefkatlidir", "Anne fedakârdır" olmak üzere üç tane, Babalar Günü reklamlarında "Baba ilgili ama otoriterdir", "Baba güçlüdür, duygularını belli etmez" ve "Baba fedakârdır" olmak üzere üç tane tema üzerinde uzlaşılmıştır. Çalışmada temalaştırma işlemi biri bağımsız iki araştırmacı tarafından ayrı ayrı yapılmış ve daha sonra karşılaştırılarak farklılık olanlar yeniden incelenerek uzlaşılmıştır.

\section{Reklamların Göstergebilimsel Analizi}

\section{Anneler Günü Reklamlarının Analizi}

\subsection{Anne Güven Verir}

Anne güven verir teması altında 3 reklam incelenmiştir. 


\begin{tabular}{lllll}
\hline & Tablo 1: Anne Güven Verir Teması Altında Değerlendirilen Reklamlar \\
\hline Reklam & Gösteren & Gösterilen & Düz Anlam & Yan Anlam \\
\hline Aptamil & $\begin{array}{l}\text { Bebeğinin } \\
\text { adımlarını takip } \\
\text { eden anne }\end{array}$ & $\begin{array}{l}\text { Anneler } \\
\text { hissettirmeseler } \\
\text { bile çocuklarının } \\
\text { attıkları adımları } \\
\text { takip ederler. }\end{array}$ & $\begin{array}{l}\text { Anneler } \\
\text { çocuklarının } \\
\text { adımlarını her } \\
\text { zaman takip } \\
\text { ederler. }\end{array}$ & $\begin{array}{l}\text { Anneler } \\
\text { koruyucudurlar. }\end{array}$ \\
\hline Ak Sigorta & $\begin{array}{l}\text { Çocuklarına sarılan } \\
\text { anne }\end{array}$ & $\begin{array}{l}\text { Anne ile çocukları } \\
\text { arasında sevgi bağı } \\
\text { vardır. }\end{array}$ & $\begin{array}{l}\text { Anneler } \\
\text { çocuklarına } \\
\text { sarılırlar. }\end{array}$ & $\begin{array}{l}\text { Anneler } \\
\text { çocuklarına güven } \\
\text { verirler. }\end{array}$ \\
\hline Renault & $\begin{array}{l}\text { Her konuda } \\
\text { annelerine danışan } \\
\text { çocuklar }\end{array}$ & $\begin{array}{l}\text { Anneler her } \\
\text { konuda } \\
\text { çocuklarına destek } \\
\text { olurlar. }\end{array}$ & $\begin{array}{l}\text { Çocukları her } \\
\text { şeyi annelerine } \\
\text { danışabilirler. }\end{array}$ & $\begin{array}{l}\text { Anne güven ve } \\
\text { destek verendir. }\end{array}$ \\
\hline
\end{tabular}

Aptamil reklamında "annenin bebeğinin adımlarını takip etmesi" göstereni ile "anneler hissettirmeseler bile çocuklarının hayatta attıkları her adımı takip ederler" düşüncesi iletilmeye çalışılmaktadır. Bu düşünce reklamdaki annenin "Her yerde yanında olamasam da her zaman arkandayım" sözleri ile desteklenmektedir. Dolayısıyla reklamda dilsel göstergelerle de görsel göstergelerin aktarmak istediği anlam desteklenmektedir. Söz konusu gösterenin düz anlamı "anneler çocuklarının adımlarını her zaman takip ederler"dir. Ortaya çıkan "anneler koruyucudurlar" anlamı ise gösterenin yan anlamıdır. Zira anne, devrilmiş bir ağaçla gösterilen çocuğunun karşısına çıkan engeli aşmasına yardımcı olmaktadır.

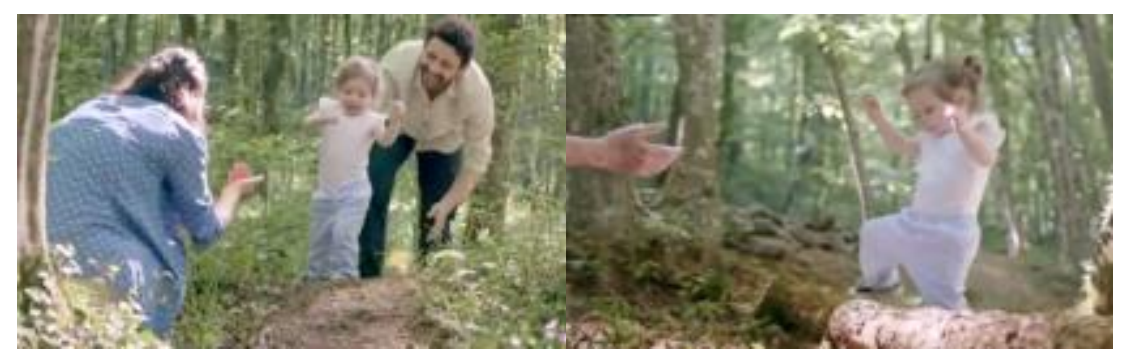

Ak Sigorta reklamında ise "annenin çocuklarına sarılması" göstereni ile "anneler ile çocukları arasında sevgi bağı" vardır gösterilenine gönderme yapılmaktadır.

Gösterenin düz anlamında fiziksel olarak "anneler çocuklarına sarılırlar" anlamı oluşturulmaktadır. Fiziksel olarak çocuğuna sarılan anne göstereni ile "anneler çocuklarına güven verir" yan anlamı aktarılmaktadır.

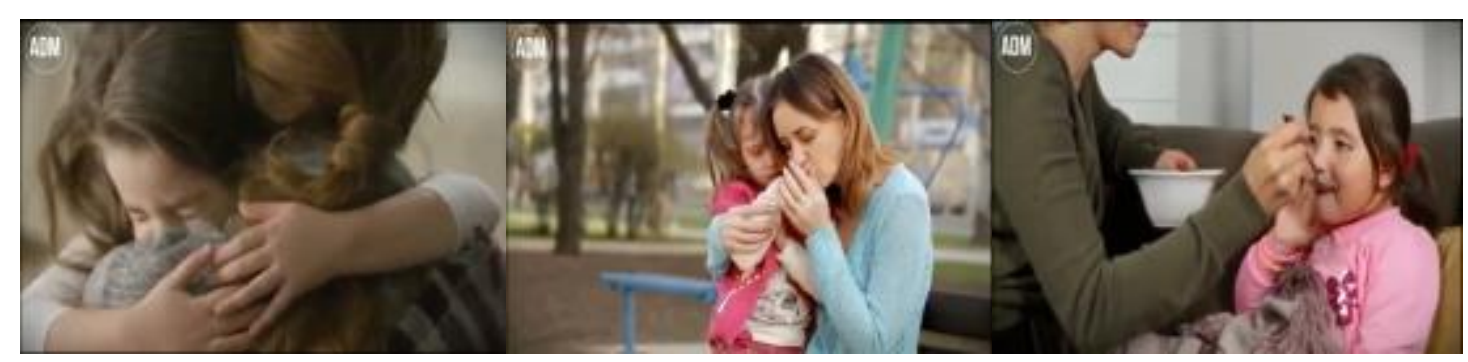

www.turkishstudies.net/turkishstudies 
Reklamda annenin çocuğuna sarılması göstereninin yanı sıra "annenin parmağı acıyan çocuğunun parmağını öpmesi”, "annenin evlenen kızına sarılması", "annenin hasta çocuğuna çorba içirmesi" gösterenleri ile de çocuklarının ihtiyaçlarını karşılayan "anneler çocuklarına güven verirler" yan anlamı aktarılmaktadır. Reklamdaki dış ses tarafindan söylenen "Hayat denen bu yolculukta yarı yolda kalmak istemiyorsan onun kollarından daha güvenlisi olabilir mi?" sözleri ile de bu yan anlam desteklenmektedir.

Renault reklamında da "çocukların her konuda annelerine danışması" göstereni ile "anneler her konuda çocuklarına destek olurlar" gösterilenine gönderme yapılmaktadır.

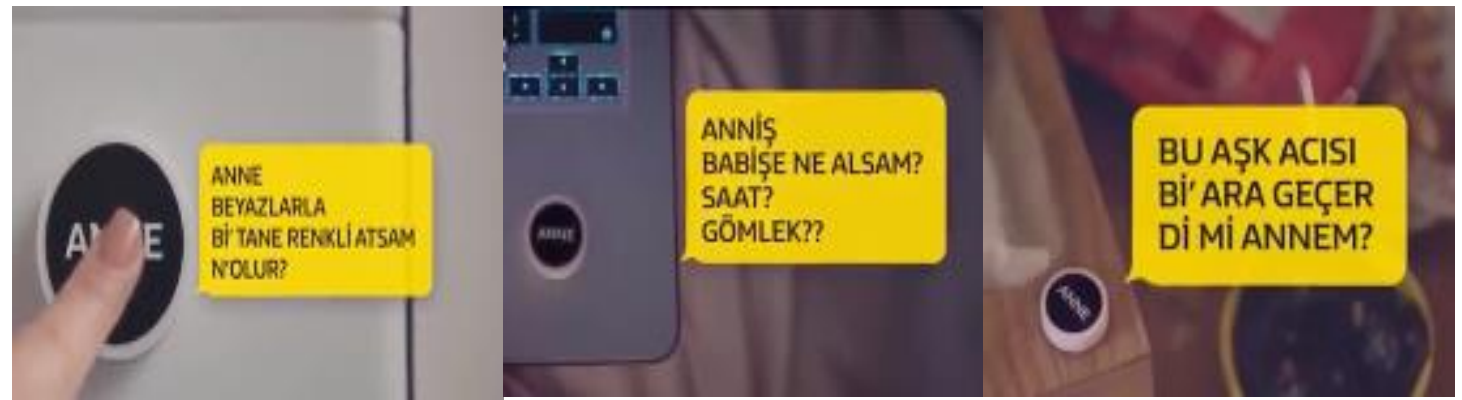

$\mathrm{Bu}$ gösterenin düz anlamı "çocuklar her şeyi annelerine danışabilirler" olarak karşımıza çıkarken, asıl aktarılmak istenen "anne güven ve destek verir" yan anlamıdır.

"Anne güven verir" teması altında incelenen reklamlar, toplumsal cinsiyet açısından değerlendirildiğinde "annelik çocuğuna güven vermeyi gerektirir" mitinin reklamlarla desteklendiği görülmektedir. Dolayısıyla toplumda anneliğin gerekliliklerinden biri olarak görülen "anne güven verir" rolü vurgulanarak toplumsal cinsiyet rollerinin altı bir kez daha çizilmektedir.

\subsection{Anne Şefkatlidir}

"Anne şefkatlidir" ortak teması altında 10 reklam incelenmiştir.

Tablo 2: Anne Şefkatlidir Teması Altında Değerlendirilen Reklamlar

\begin{tabular}{lllll}
\hline Reklam & Gösteren & Gösterilen & Düz Anlam & Yan Anlam \\
\hline Altınbaş & $\begin{array}{l}\text { Uyuyan bebeğini } \\
\text { izleyen, oğlunun } \\
\text { başını okşayan, } \\
\text { kızının saçını tarayan } \\
\text { anne }\end{array}$ & $\begin{array}{l}\text { Anneler farklı } \\
\text { yollarla da olsa } \\
\text { çocuklarına şefkat } \\
\text { gösterirler. }\end{array}$ & $\begin{array}{l}\text { Anneler çocukları } \\
\text { ile fiziksel temas } \\
\text { kurarlar. }\end{array}$ & $\begin{array}{l}\text { Anneler } \\
\text { şefkatlidirler. }\end{array}$ \\
\hline Arçelik & $\begin{array}{l}\text { Annesi dışında teyze, } \\
\text { hala gibi diğer } \\
\text { yakınlarının kişiye } \\
\text { olan davranışları }\end{array}$ & $\begin{array}{l}\text { Anne dişındaki teyze, } \\
\text { hala gibi kadın } \\
\text { akrabalar da kişiye } \\
\text { anne şefkati } \\
\text { gösterirler. }\end{array}$ & $\begin{array}{l}\text { Teyze, hala gibi } \\
\text { yakın kadın } \\
\text { akrabaların da } \\
\text { anneler günü } \\
\text { kutlanmalıdır. }\end{array}$ & $\begin{array}{l}\text { Anne dişında } \\
\text { kadın akrabalar da } \\
\text { anne şefkati } \\
\text { gösterirler. }\end{array}$ \\
\hline Atasay & $\begin{array}{l}\text { Kızına ve torununa } \\
\text { sarılan anne }\end{array}$ & $\begin{array}{l}\text { Anneler sevgilerini } \\
\text { sarılarak gösterirler. }\end{array}$ & $\begin{array}{l}\text { Anneler } \\
\text { çocuklarına } \\
\text { sarılırlar. }\end{array}$ & $\begin{array}{l}\text { Anneler sevgi ve } \\
\text { şefkat doludurlar. }\end{array}$ \\
\hline Canbebe & $\begin{array}{l}\text { Bebeğini koklayan } \\
\text { anne }\end{array}$ & $\begin{array}{l}\text { Anneler sevgi } \\
\text { doludurlar. }\end{array}$ & $\begin{array}{l}\text { Anneler çocukları } \\
\text { ile fiziksel temas } \\
\text { kurarlar. }\end{array}$ & $\begin{array}{l}\text { Anneler } \\
\text { şefkatlerini farklı } \\
\text { yollarla gösterirler. }\end{array}$
\end{tabular}




\begin{tabular}{|c|c|c|c|c|}
\hline Corega & $\begin{array}{l}\text { Ağlayan torununu } \\
\text { susturan anneanne }\end{array}$ & $\begin{array}{l}\text { Anneler sevgilerini } \\
\text { her durumda } \\
\text { gösterirler. }\end{array}$ & $\begin{array}{l}\text { Anneler } \\
\text { sevgilerini güler } \\
\text { yüzle gösterirler. }\end{array}$ & $\begin{array}{l}\text { Anneler sevgi } \\
\text { doludurlar. }\end{array}$ \\
\hline $\begin{array}{l}\text { Garanti } \\
\text { Bankası }\end{array}$ & $\begin{array}{l}\text { Dikkatli olması için } \\
\text { çocuğu uyaran otobüs } \\
\text { şoförü, çocuğa kazak } \\
\text { ören müdür, çocuğun } \\
\text { sırtına havlu koyan } \\
\text { güvenlik görevlisi, } \\
\text { çocuğa TV alan } \\
\text { mağaza çalışanı, } \\
\text { sosisli sandviç yerine } \\
\text { sarma ve salata } \\
\text { getiren büfeci }\end{array}$ & $\begin{array}{l}\text { Anneler çocuklarının } \\
\text { sağlığını, iyiliğini, } \\
\text { mutluluğunu isterler. } \\
\text { Bunun için de } \\
\text { çocuklarına ilgi } \\
\text { gösterirler. }\end{array}$ & $\begin{array}{l}\text { Anneler, } \\
\text { çocuklarını } \\
\text { koruyup kollarlar. }\end{array}$ & $\begin{array}{l}\text { Anneler her zaman } \\
\text { şefkatli ve } \\
\text { koruyucudurlar. } \\
\text { Çocuklarına olan } \\
\text { ilgi ve sevgilerini } \\
\text { farklı yollarla } \\
\text { gösterirler. }\end{array}$ \\
\hline $\begin{array}{l}\text { İş Bankası } \\
\text { Maximum }\end{array}$ & $\begin{array}{l}\text { Yemek hazırlayan } \\
\text { anne, kendisine } \\
\text { hediye alan çocuğuna } \\
\text { sarılan anne }\end{array}$ & $\begin{array}{l}\text { Anneler sevgi } \\
\text { doludurlar. }\end{array}$ & $\begin{array}{l}\text { Anneler, } \\
\text { çocuklarını } \\
\text { koruyup kollarlar. }\end{array}$ & $\begin{array}{l}\text { Anneler her zaman } \\
\text { şefkatli, koruyucu } \\
\text { ve ilgilidirler. } \\
\text { Kendilerinden çok } \\
\text { çocuklarını } \\
\text { düşünürler. }\end{array}$ \\
\hline Pegasus & $\begin{array}{l}\text { Çocuğuna sevgi ile } \\
\text { bakan anne }\end{array}$ & $\begin{array}{l}\text { Anneler sevgi } \\
\text { doludurlar. }\end{array}$ & $\begin{array}{l}\text { Anneler } \\
\text { çocuklarına sevgi } \\
\text { dolu bakarlar. }\end{array}$ & $\begin{array}{l}\text { Anneler attıkları } \\
\text { her adımda } \\
\text { çocuklarının } \\
\text { yanındadır ve } \\
\text { onlara cesaret } \\
\text { verirler. }\end{array}$ \\
\hline Pharmaton & $\begin{array}{l}\text { Annelerini öpen } \\
\text { çocuklar }\end{array}$ & $\begin{array}{l}\text { Anneler ile çocukları } \\
\text { arasında sevgi bağı } \\
\text { vardır. }\end{array}$ & $\begin{array}{l}\text { Çocuklar } \\
\text { annelerini öperek } \\
\text { sevgilerini } \\
\text { gösterirler. }\end{array}$ & $\begin{array}{l}\text { Annelere sevgi } \\
\text { doludur ve sevgiyi } \\
\text { hak ederler. }\end{array}$ \\
\hline Ülker & $\begin{array}{l}\text { Kızının önlük } \\
\text { yakasını takan, hasta } \\
\text { kızına bakan, uzaktaki } \\
\text { kızı ile görüntülü } \\
\text { konușan anne }\end{array}$ & $\begin{array}{l}\text { Anneler zorlukların } \\
\text { üstesinden } \\
\text { gelmesinde } \\
\text { çocuklarına destek } \\
\text { olurlar. }\end{array}$ & $\begin{array}{l}\text { Anneler ihtiyaçları } \\
\text { olduğunda } \\
\text { çocuklarının } \\
\text { yanındadırlar. }\end{array}$ & $\begin{array}{l}\text { Anneler } \\
\text { çocuklarına daima } \\
\text { sevgi ve şefkat } \\
\text { gösterirler. }\end{array}$ \\
\hline
\end{tabular}

Altınbaş reklamında "uyuyan bebeğini izleyen anne", "oğlunun başını okşayan anne", kızını saçını tarayan anne" gösterenleri ile "anneler farklı yollarla da olsa çocuklarına şefkat gösterirler" gösterilenine gönderme yapılmaktadır. Gösterenin düz anlamı "anneler çocukları ile fiziksel temas kurarlar" olarak kurulurken asıl vurgu "anneler şefkatlidirler" yan anlamına yapılmaktadır. Arçelik reklamında "çocukla oyun oynayan teyze", "maçta çocuğu destekleyen yenge", "çocuğa para veren hala" gösterenleri ile "anne dışındaki kadın yakın akrabalar da kişiye anne şefkati gösterirler" gösterilenine gönderme yapılmaktadır. Reklamda kişilere yakın kadın akrabaların da "anneler günü kutlanmalıdır" düz anlamı kurulurken "Anne dışında teyze, hala gibi yakın kadın akrabalar da anne şefkati gösterirler" yan anlamına vurgu yapılmaktadır. Bu yan anlam "Annelerimizin ve anne şefkatini üzerimizden eksik etmeyen tüm kadınların anneler günü kutlu olsun” dilsel göstergesi ile de desteklenmektedir. 


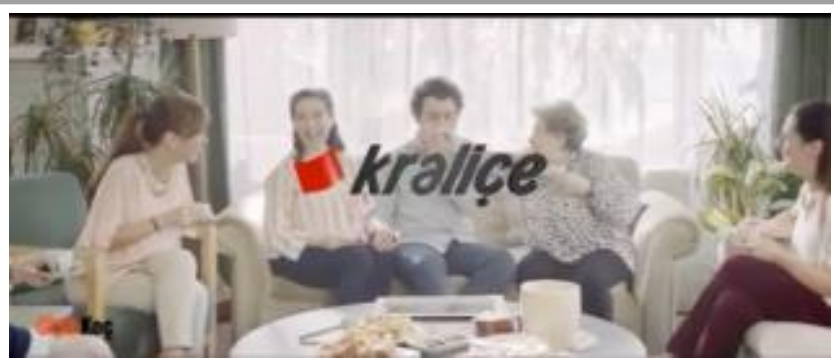

Atasay reklamında "kızına ve torununa sarılan anneanne", Canbebe reklamında "bebeğini koklayan anne", Corega reklamında "kızına sarılan ve ağlayan torununu susturan anne" gösterenleri ile "anneler sevgi doludurlar" gösterileni çağrıştırılmaktadır. Bu reklamlarda "anneler çocukları ile fiziksel temas kurarlar" düz anlamı ortaya çıkmaktadır. Bu düz anlamın gerisinde ise "Anneler sevgi ve şefkatlerini farklı yollarla gösterirler" yan anlamı bulunmaktadır. Reklamda anneye alınan "kahve makinesi" hediyesi de dikkat çekmektedir. Annenin toplumdaki ev işlerini yapan kişi rolünün altı bu hediye ile bir kez daha çizilmektedir.

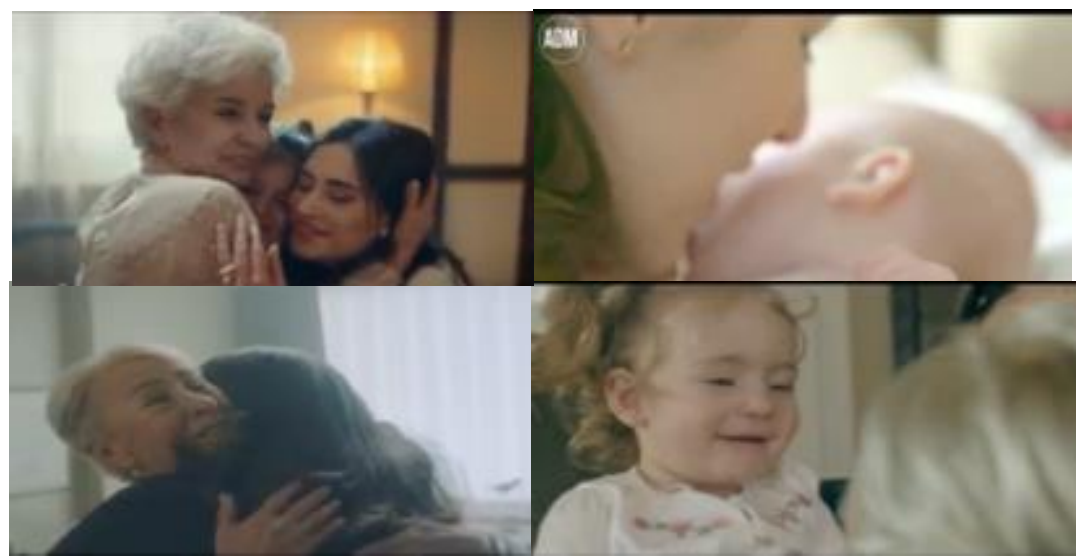

Garanti reklamında "dikkatli olması için çocuğu uyaran otobüs şoförü”, "çocuğa kazak ören müdür", "çocuğun sırtına havlu koyan güvenlik görevlisi", "çocuğa televizyon alan mağaza görevlisi", "sosisli sandviç isteyen çocuğa sarma getiren büfeci" gösterenleri ile annelik rolleri farklı karakterlere yüklenerek verilmiş, böylece "Annelerin çocuklarının sağlığını, iyiliğini, mutluluğunu istedikleri, bunun için de çocuklarına ilgi gösterdikleri" anlamı kurulmuştur. "Anneler çocuklarını koruyup kollarla" düz anlamının gerisinde "Anneler her zaman şefkatli ve koruyucudurlar. Çocuklarına olan ilgi ve sevgilerini farklı yollarla gösterirler." yan anlamı bulunmaktadır. İş Bankası reklamında da "yemek hazırlayan anne", "kendisine hediye alan çocuğuna sarılan anne" gösterenleri ile "anneler sevgi doludurlar" gösterileni çağrıştırılmaktadır.

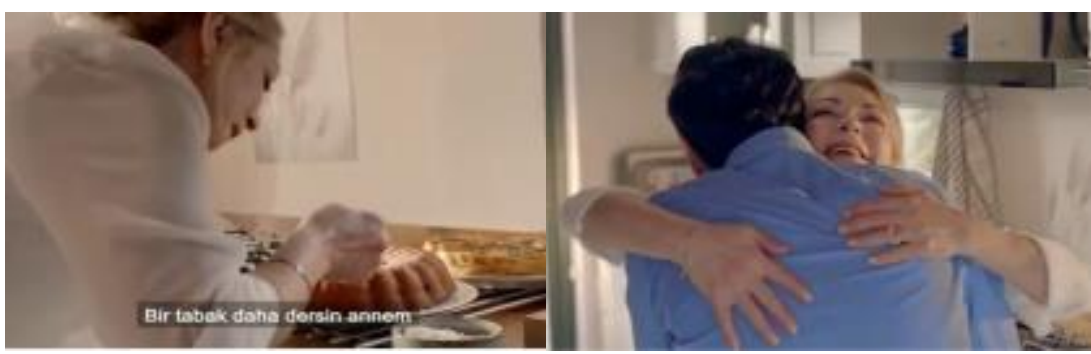

Reklamın jenerik müziğinde geçen "Gece geç kalınca pencerede beklersin annem. Koltukta uyusam üstümü örtersin annem. Doydum desem bir tabak daha dersin annem. Kollarından taşsam 
ile, boyunu geçsem nafile. Küçük ama küçüktüm hep gözünde” şeklindeki dilsel göstergeler ile de "Anneler her zaman şefkatli, koruyucu ve ilgilidirler. Kendilerinden çok çocuklarını düşünürler." yan anlamı desteklenmektedir.

Pegasus reklamında da "çocuğuna sevgi ile bakan anne" göstereni ile diğer reklamlarda olduğu gibi "anneler sevgi doludurlar" anlamı kurulmaya çalıșılmaktadır. Dolayısıyla "Anneler çocuklarına sevgi dolu bakarlar" düz anlamının gerisinde "Anneler her zaman sevgi doludur ve attıkları her adımda çocuklarının yanındadır ve onlara cesaret verirler" yan anlamı bulunmaktadır.

Pharmaton reklamında "annesini öpen çocuk" göstereni ile "anneler ile çocuklar arasındaki sevgi bağı" gösterilmektedir. "Çocuklar da anneler gibi sevgilerini fiziksel temasla gösterirler" düz anlamının gerisinde ise "annelere sevgi gösterilmelidir" yan anlamı bulunmaktadır. Bu yan anlam "Bize söz veriyorsunuz annenizi çok öpüyorsunuz" dilsel göstergesi ile de desteklenmektedir.

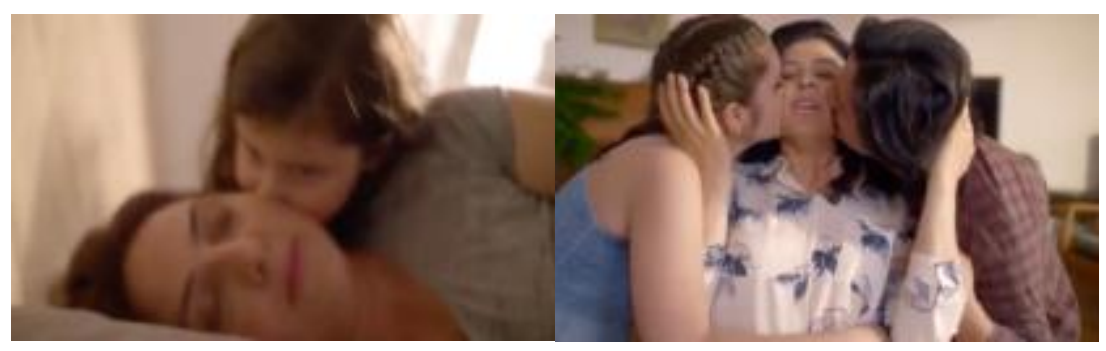

Ülker reklamında "kızının önlük yakasınız takmasına yardım eden anne", hasta kızına bakan anne" ve "uzaktaki kızı ile görüntülü konuşan anne" gösterenleri ile "annelerin tüm zorlukların üstesinden gelmede çocuklarına destek oldukları" gösterilmektedir. "Anneler ihtiyaçları olduğunda çocuklarının yanındadırlar" düz anlamının gerisinde ise "Anneler çocuklarına daima sevgi ve şefkat gösterirler" yan anlamı bulunmaktadır.

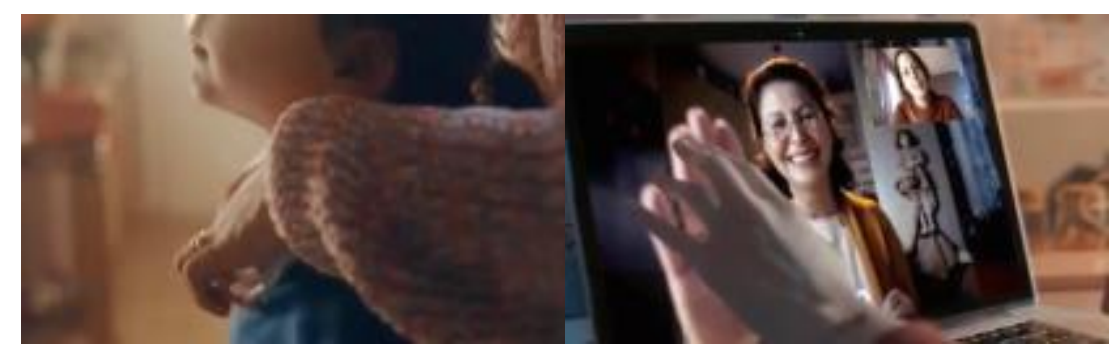

Reklamda kurulan yan anlam "Anne eli bir değer, dersin ki işte budur", "Anne eli bir değer, her şey yolunu bulur", "Anne eli bir değer, yalnızlığın yok olur" dilsel göstergeleri ile de desteklenmektedir.

"Anne şefkatlidir" teması altında incelenen reklamlara bakıldığında "anne güven verir" teması altında incelenen reklamlarda olduğu gibi toplumda anneye biçilen rollerin tekrarlandığı ve yeniden üretildiği, dolayısıyla toplumsal cinsiyet rollerinin tekrar edildiği görülmektedir.

\subsection{Anne Fedakârdır}

Anne fedakârdır teması altında 4 reklam incelenmiştir. 
Tablo 3: Anne Fedakârdır Teması Altında Değerlendirilen Reklamlar

\begin{tabular}{|c|c|c|c|c|}
\hline Reklam & Gösteren & Gösterilen & Düz Anlam & Yan Anlam \\
\hline Çaykur & $\begin{array}{l}\text { Çocuğu ağladığı için, } \\
\text { çocuğuna yemek } \\
\text { yedirmeye çalışırken, } \\
\text { sinavdaki çocuğunu } \\
\text { dışarıda beklerken, } \\
\text { çocuğunun derdini } \\
\text { dinlerken, fotoğraflarına } \\
\text { bakarken çayını } \\
\text { içemeyen anne }\end{array}$ & $\begin{array}{l}\text { Anneler çocukları } \\
\text { için kendilerinden } \\
\text { vazgeçerler. }\end{array}$ & $\begin{array}{l}\text { Anneler çocukları } \\
\text { için her şeyi } \\
\text { yaparlar. }\end{array}$ & $\begin{array}{l}\text { Anneler } \\
\text { fedakârdırlar. }\end{array}$ \\
\hline ING Bank & $\begin{array}{l}\text { Çocuğunun evlenmesini } \\
\text { değil, meslek sahibi } \\
\text { olmasını isteyen; baskı } \\
\text { yapmayan, hayatına } \\
\text { karışmayan anne }\end{array}$ & $\begin{array}{l}\text { Anneler daima } \\
\text { çocukları için her } \\
\text { şeyin en iyisini } \\
\text { isterler ve bunun } \\
\text { için kendi } \\
\text { hayatlarından } \\
\text { fedakârlık ederler. }\end{array}$ & $\begin{array}{l}\text { Anneler çocukları } \\
\text { için her şeyi } \\
\text { yaparlar. }\end{array}$ & $\begin{array}{l}\text { Anneler } \\
\text { fedakârdırlar. }\end{array}$ \\
\hline Network & $\begin{array}{l}\text { Çalışırken, ev işi } \\
\text { yaparken bir yandan da } \\
\text { çocuğu ile ilgilenen anne }\end{array}$ & $\begin{array}{l}\text { Anneler ne } \\
\text { yaparlarsa } \\
\text { yapsınlar aynı } \\
\text { zamanda } \\
\text { çocuklarını da } \\
\text { düşünürler. }\end{array}$ & $\begin{array}{l}\text { Anneler çocukları } \\
\text { için çalışırlar. }\end{array}$ & $\begin{array}{l}\text { Anneler } \\
\text { kendilerinden çok } \\
\text { çocuklarını } \\
\text { düşünürler ve } \\
\text { onlar için kendi } \\
\text { hayatlarından } \\
\text { fedakârlık ederler. }\end{array}$ \\
\hline $\begin{array}{l}\text { Türk } \\
\text { Telekom }\end{array}$ & $\begin{array}{l}\text { Çocuğunun kendisini } \\
\text { ihmal etmesi karşısında } \\
\text { bile hep anlayışlı } \\
\text { davranan anne }\end{array}$ & $\begin{array}{l}\text { Anneler daima } \\
\text { anlayışlıdırlar. }\end{array}$ & $\begin{array}{l}\text { Anneler } \\
\text { üzüntülerini belli } \\
\text { etmezler. }\end{array}$ & $\begin{array}{l}\text { Anneler üzülseler } \\
\text { de çocuklarına } \\
\text { karşı hep } \\
\text { anlayışlıdırlar. }\end{array}$ \\
\hline
\end{tabular}

"Anne fedakârdır" teması altında değerlendirilen Çaykur reklamında "ağlayan çocuğunu susturmak için çayını içemeyen anne", "çocuğuna yemek yedirmeye çalıştığı için çayını içemeyen anne", "sınavdaki çocuğunu beklerken çayını içemeyen anne", "çocuğunun derdini dinlerken çayını içemeyen anne", "çocuğunun fotoğraflarına bakarken çayını içemeyen anne" gösterenleri ile "anneler çocukları için kendilerinden vazgeçerler" gösterilenine gönderme yapılmaktadır. "Anneler çocukları için her şeyi yaparlar" düz anlamı verilerek "anneler fedakârdır" yan anlamı kurulmaktadır.

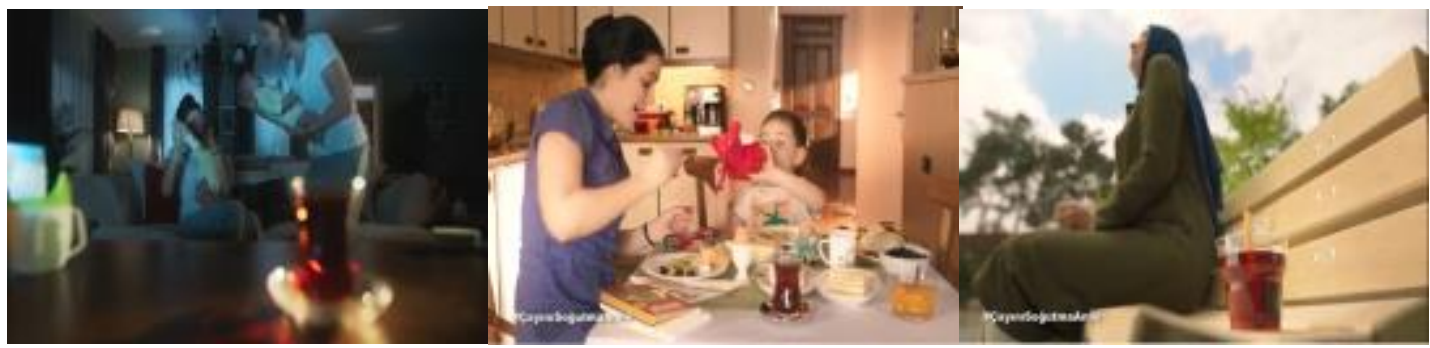

ING Bank reklamında da "Anneler çocukları için ne yapmaz" sloganı ile annelerin fedakârlığı vurgulanmakta ve "çocuğunun evlenmesini değil, meslek sahibi olmasını isteyen anne", "çocuğuna bask1 yapmayan anne" gösterenleri ile "Anneler daima çocukları için her şeyin en iyisini isterler ve bunun için kendi hayatlarından fedakârlık ederler." anlamı kurulmaktadır. 


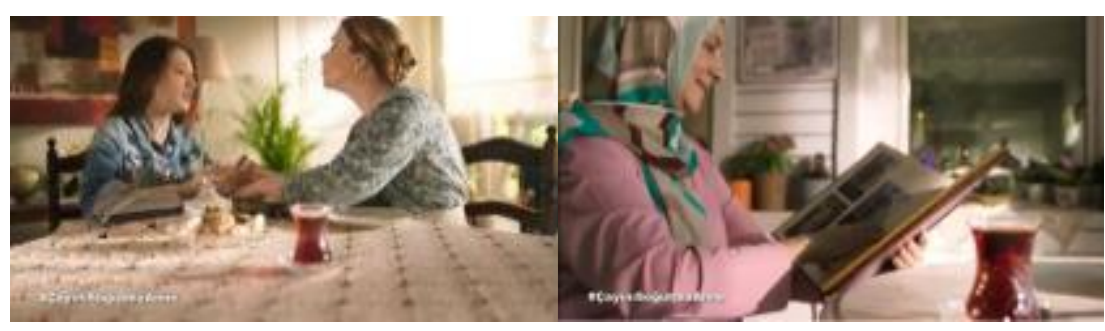

Network reklamında "annelik fedakârlıktır" yan anlamı "çalışırken ve ev işi yaparken aynı zamanda çocuğu ile ilgilenen anne" göstereni üzerinden kurulmaktadır. "Anneler ne yaparlarsa yapsınlar aynı zamanda çocuklarını da düşünürler." anlamı kurularak "Anneler çocukları için çalışırlar ve onları düşünürler, onlar için kendi hayatlarından fedakârlık ederler." vurgusu yapılmaktadır.

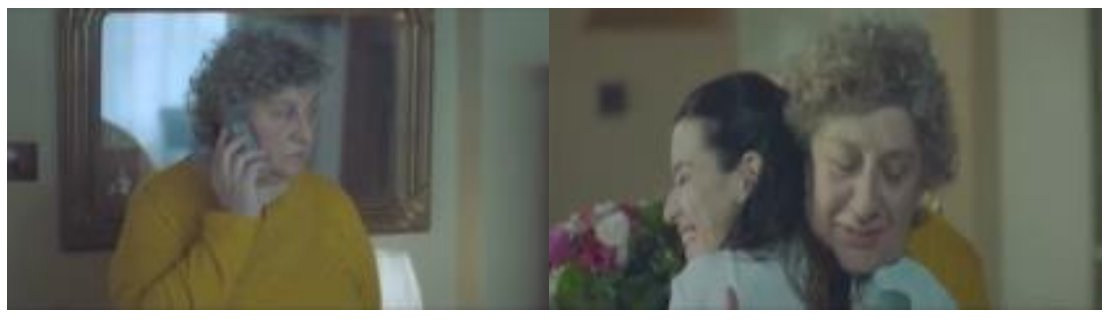

Türk Telekom reklamında ise annelerin daima çocuklarına karşı anlayışlı oldukları vurgusu yapılmaktadır. $\mathrm{Bu}$ anlam "Çocuğunun kendisini ihmal etmesi karşısında hep anlayışlı davranan anne" göstereni ile kurulmaktadır. "Anneler üzüntülerini belli etmez" düz anlamının gerisinde "Anneler daima anlayışılı ve fedakârdırlar" yan anlamı bulunmaktadır.

"Anne güven verir" ve "Anne şefkatlidir" temalarında olduğu gibi "Annelik fedakârlıktır" teması altında incelenen reklamlarda da kadına atfedilen toplumsal cinsiyet rollerinin tekrarlandığ 1 görülmektedir. Dolayısıyla anneler günü reklamlarının tamamında annelik güven vermeyi, şefkatli, sevgi dolu, anlayışlı ve fedakâr olmayı gerektirir miti desteklenmektedir. Böylece toplumsal cinsiyet rolleri reklamlar aracılığıyla da bir kez daha ayrıştırılmakta ve belirginleştirilmektedir.

\section{Babalar Günü Reklamlarının Analizi}

\subsection{Baba İlgili Ama Otoriterdir}

Baba ilgili ama otoriterdir teması altında 3 reklam incelenmiştir.

Tablo 4: Baba İlgili Ama Otoriterdir Teması Altında Değerlendirilen Reklamlar

\begin{tabular}{|c|c|c|c|c|}
\hline Reklam & Gösteren & Gösterilen & Düz Anlam & Yan Anlam \\
\hline $\begin{array}{l}\text { Axa } \\
\text { Sigorta }\end{array}$ & $\begin{array}{l}\text { Çocuğu ile dans eden / } \\
\text { oyun oynayan baba, } \\
\text { temizlik yapan baba, } \\
\text { çalışıp para kazanan, } \\
\text { çocuğuna bakan baba }\end{array}$ & $\begin{array}{l}\text { Babalar da anneler } \\
\text { kadar ilgilidirler. }\end{array}$ & $\begin{array}{l}\text { Babalar çocukları } \\
\text { ile ilgilenirler. }\end{array}$ & $\begin{array}{l}\text { Babalar da } \\
\text { çocukları ile } \\
\text { anneleri kadar } \\
\text { ilgilenir fakat bu } \\
\text { görülmemektedir. }\end{array}$ \\
\hline De Facto & $\begin{array}{l}\text { Çocukları ile oyun } \\
\text { oynayan, uçurtma } \\
\text { uçuran, parka giden } \\
\text { baba }\end{array}$ & $\begin{array}{l}\text { Babalar çocukları } \\
\text { ile iyi vakit } \\
\text { geçirirler ve onlarla } \\
\text { ilgilenirler. }\end{array}$ & $\begin{array}{l}\text { Babalar çocukları } \\
\text { ile vakit } \\
\text { geçirirler. }\end{array}$ & $\begin{array}{l}\text { Babalar çocukları } \\
\text { ile güzel vakit } \\
\text { geçirir ve onlarla } \\
\text { ilgilenirler. }\end{array}$ \\
\hline Mondi & $\begin{array}{l}\text { Babalar tarafindan } \\
\text { kurulan cümleler }\end{array}$ & $\begin{array}{l}\text { Babalar kendilerine } \\
\text { özgü cümleleri ile } \\
\text { otoritelerini belli } \\
\text { ederler. }\end{array}$ & $\begin{array}{l}\text { Babaların } \\
\text { kendilerine özgü } \\
\text { cümleleri vardır. }\end{array}$ & $\begin{array}{l}\text { Babalar } \\
\text { otoriterdirler. }\end{array}$ \\
\hline
\end{tabular}


"Babalar İlgili Ama Otoriterdir" teması altında incelenen reklamlardan Axa Sigorta ve De Facto reklamlarında babaların da çocukları ile ilgilendiği vurgusu yapılırken, Mondi reklamında ağırlıklı olarak babanın otoriter rolüne vurgu yapılmıştır.

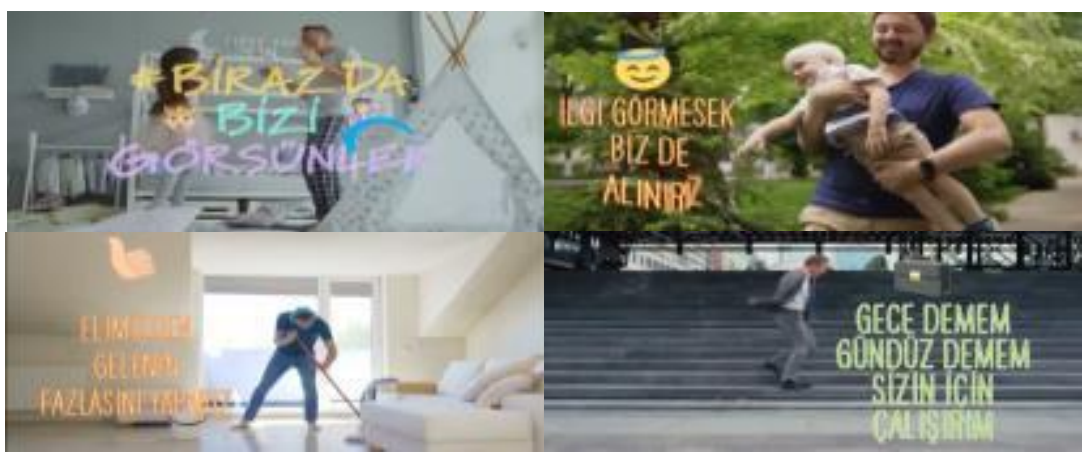

Axa Sigorta reklamlarından alınan yukarıdaki görsellerde de görüldüğü gibi “çocuğu ile dans eden, oyun oynayan, temizlik yapan, çalışıp para kazanan, çocuğuna bakan baba" gösterenleri ile babaların da anneler kadar çocukları ile ilgili olduğu anlamı kurulmaktadır. Ancak reklamda dikkat çeken nokta, babanın ailedeki çalışıp para kazanan kişi rolüdür. Anneler günü reklamlarında annenin iş hayatındaki yeri üzerine bir vurgu yapılmazken babalar günü reklamlarında böyle bir vurgunun olması toplumsal cinsiyet rolleri açısından dikkat çekmektedir. Her ne kadar baba, anne kadar ilgili olsa da evin geçimini sağlayan yine de babadır anlamı kurulmaktadır. "Gece demem, gündüz demem sizin için çalışırım" cümlesi de bu anlamın kurulmasını desteklemektedir. Reklamın "Biraz da bizi görsünler" sloganının gerisinde de "babalar da anneler kadar çocuklarına karşı ilgilidir fakat bu görülmemektedir" yan anlamı bulunmaktadır. Bu anlam "İlgi görmesek biz de alınırız", "Elimizden gelenin fazlasını yaparız" dilsel göstergeleri ile de desteklenmektedir.

De Facto reklamında da "çocukları ile oyun oynayan, parka giden, uçurtma uçuran baba" gösterenleri ile "Babalar çocukları ile iyi vakit geçirirler ve onlarla ilgilenirler." gösterilenine gönderme yapılmaktadır.

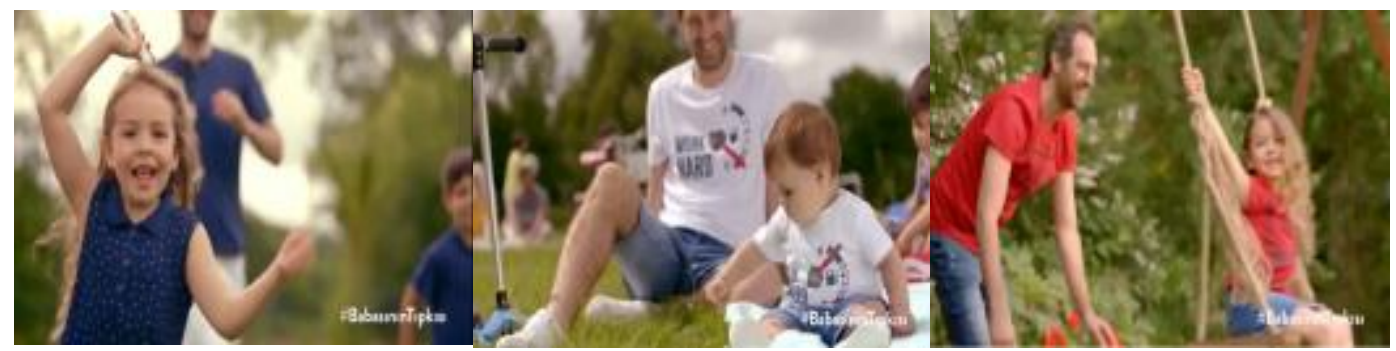

De Facto reklamından alınan yukarıdaki görsellerle "Babalar çocukları ile güzel vakit geçirir ve onlarla ilgilenirler." yan anlamı kurulmaktadır. Axa Sigorta reklamında olduğu gibi De Facto reklamında da ilgili baba rolüne vurgu yapılması, toplumsal cinsiyet açısından babaya yüklenen rollerin kırılmaya çalışıldığını göstermektedir. Öyle ki baba, toplumda daha çok çalışan, çocukları ile mesafeli, otoriter bir figür olarak kodlanmaktadır. Her ne kadar Axa Sigorta reklamında çalışıp para kazanan baba rolüne vurgu yapılmış olsa da her iki reklamda da "ilgili baba" rolünün daha çok ön plana çıkarılmaya çalışıldığı dikkat çekmektedir.

Mondi reklamı ise iki reklamdan farklı olarak babanın toplumdaki otoriter rolüne vurgu yapmaktadır. Dilsel ve işitsel göstergelerin kullanıldığı reklamda daha çok babalar tarafından kurulan cümleler bulunmaktadır. 


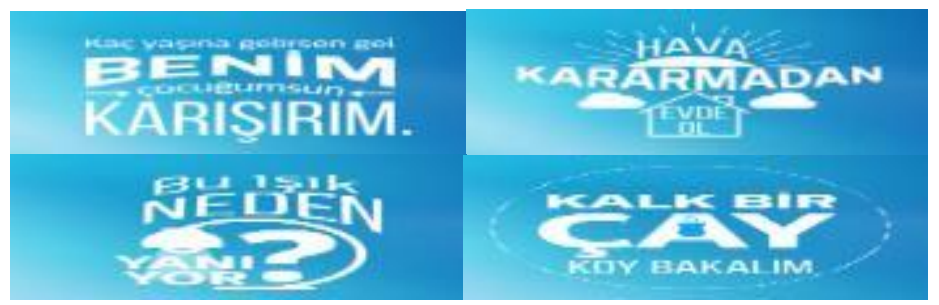

Yukarıdaki görsellerde de görüldüğü gibi reklamda dilsel göstergeler, işitsel göstergelerle tamamlanmaktadır. Babalara özgü olan ve çoğunlukla "emir kipi” ile çekimlenen cümleler, reklamda otoriter bir ses tonuyla söylenmekte bu da "babalar otoriterdir" anlamının kurulmasını sağlamaktadır.

İncelenen reklamlara bakıldığında babanın toplumdaki geleneksel rolünün kırılmaya çalışıldığı babalarında da annelere gibi çocuklarına karşı ilgili olduğu vurgusunun yapıldığı görülmektedir. Bununla birlikte yine de toplumda var olan "baba otoriterdir" mitinin tekrarlandığ 1 görülmektedir.

\subsection{Baba Güçlüdür, Duygularını Belli Etmez}

Baba güçlüdür, duygularını belli etmez teması altında 5 reklam incelenmiştir.

Tablo 5: Baba Güçlüdür, Duygularını Belli Etmez Teması Altında Değerlendirilen Reklamlar

\begin{tabular}{|c|c|c|c|c|}
\hline Reklam & Gösteren & Gösterilen & Düz Anlam & Yan Anlam \\
\hline Bonus & $\begin{array}{l}\text { Babalar gününü } \\
\text { önemsemiyormuş gibi } \\
\text { görünen baba }\end{array}$ & $\begin{array}{l}\text { Babalar duygularını } \\
\text { belli etmezler. }\end{array}$ & $\begin{array}{l}\text { Babalar her ne kadar } \\
\text { belli etmeseler de } \\
\text { babalar gününü } \\
\text { önemserler. }\end{array}$ & $\begin{array}{l}\text { Babalar } \\
\text { duygusaldır fakat } \\
\text { bunu belli } \\
\text { etmezler. }\end{array}$ \\
\hline Doğtaş & $\begin{array}{l}\text { Çocuğunun doğumunu, } \\
\text { ilk adımını ayakta } \\
\text { bekleyen baba, } \\
\text { mezuniyetinde çocuğunu } \\
\text { ayakta alkışlayan baba }\end{array}$ & $\begin{array}{l}\text { Babalar iyi/kötü } \\
\text { tüm zamanlarda } \\
\text { güçlü dururlar. }\end{array}$ & Babalar güçlüdürler. & $\begin{array}{l}\text { Babalar her } \\
\text { koşulda güçlüdür } \\
\text { ancak aynı } \\
\text { zamanda belli } \\
\text { etmeseler de } \\
\text { duygusaldırlar ve } \\
\text { daima çocuklarına } \\
\text { destek olurlar. }\end{array}$ \\
\hline $\begin{array}{l}\text { Kemal } \\
\text { Tanca }\end{array}$ & $\begin{array}{l}\text { Eline çivi ile vuran baba, } \\
\text { izlediği filmden etkilenip } \\
\text { ağlayan baba, kendisine } \\
\text { yapılan sürpriz karşısında } \\
\text { çok sevinen ancak belli } \\
\text { etmeyen baba }\end{array}$ & $\begin{array}{l}\text { Babalar acı } \\
\text { çekseler, üzülseler } \\
\text { ya da çok sevinseler } \\
\text { dahi duygularını } \\
\text { göstermez kendi } \\
\text { içlerinde yaşarlar. } \\
\end{array}$ & Babalar güçlüdürler. & $\begin{array}{l}\text { Babaların güçlü } \\
\text { görünümlerinin } \\
\text { ardında aslında } \\
\text { duygusal bir yan } \\
\text { vardır. }\end{array}$ \\
\hline Opet & $\begin{array}{l}\text { Gök gürültüsünden } \\
\text { korkan torununun başını } \\
\text { okşayan dede, evi } \\
\text { taşırken ağır koliler } \\
\text { kaldıran anne, morali } \\
\text { bozuk olan çırağı ile } \\
\text { dertleşen usta }\end{array}$ & $\begin{array}{l}\text { Birine babalık } \\
\text { yapmak için kan } \\
\text { bağı olması } \\
\text { gerekmez. }\end{array}$ & $\begin{array}{l}\text { Yürekten hisseden } \\
\text { herkes babalık } \\
\text { yapabilir. }\end{array}$ & $\begin{array}{l}\text { Babalar daima } \\
\text { güçlüdür ve kişiye } \\
\text { güven verirler. }\end{array}$ \\
\hline Suvari & $\begin{array}{l}\text { Çocuğunu arkasında } \\
\text { saklayan, kızı ile satranç } \\
\text { oynayan, oğlunu yolcu } \\
\text { eden baba }\end{array}$ & $\begin{array}{l}\text { Babalar daima } \\
\text { koruyan, kollayan, } \\
\text { güven verendir. }\end{array}$ & $\begin{array}{l}\text { Babalar çocuklarının } \\
\text { yanındadırlar. }\end{array}$ & $\begin{array}{l}\text { Babalar } \\
\text { çocuklarının gizli } \\
\text { kahramanıdırlar. }\end{array}$ \\
\hline
\end{tabular}

"Baba güçlüdür, duygularını belli etmez" teması altında incelenen" reklamlarda genel olarak babaların duygularını belli etmeyen güçlü kişiler olduklarına vurgu yapılmaktadır. Bonus reklamında 
"babalar duygusaldır fakat bunu belli etmezler" yan anlamı, "Babalar gününü önemsemiyormuş gibi görünen baba" göstereni üzerinden kurulmaktadır. Reklamda kendi aralarında Babalar Günü'nün ne zaman olduğunu ve çocukları tarafından unutulup unutulmayacaklarını, Babalar Günü'nü bekleme heyecanlarını paylaşmakta, ancak çocukları Babalar Günü'nü kutladıklarında unutmuş, bu günü önemsemiyormuş gibi davranmaktadırlar.

Doğtaş reklamında fotoğraf kareleri ile "çocuğunun doğumunu, ilk adımını ayakta bekleyen baba", "mezuniyette çocuğunu ayakta alkışlayan baba", "çocuğunun yarasına müdahale eden baba", "çocuğuna hayatı öğreten baba" profilleri çizilmektedir.
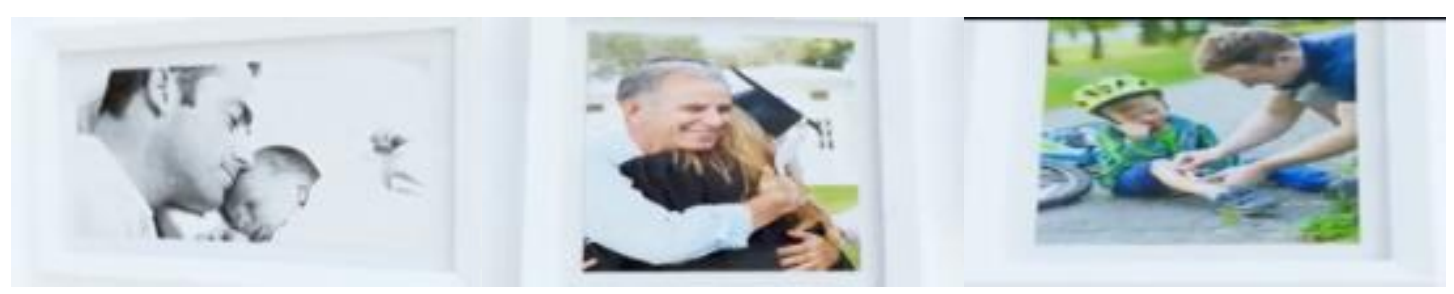

Reklamdaki bu gösterenler "O, siz doğarken doğumhanenin kapısında endişeyle ayakta bekledi.", "İlk adımlarınızda ona doğru yürümenizi hevesle beklerken ayakta duruyordu.", "Mezuniyet töreninizde sizi ayakta alkışlayan yine oydu.", "En kötü anınızda iyimserlikle dimdik ayaktaydı.", "Ondan öğrendikleriniz sayesinde hayatta ayaklarınız hep yere bastı" dilsel göstergeleri ile de desteklenerek "güçlü baba profiline vurgu yapılmıştır. Böylece toplumsal cinsiyet rolleri açısından babaya yüklenen "güçlülük" durumu bir kez daha yinelenmektedir.

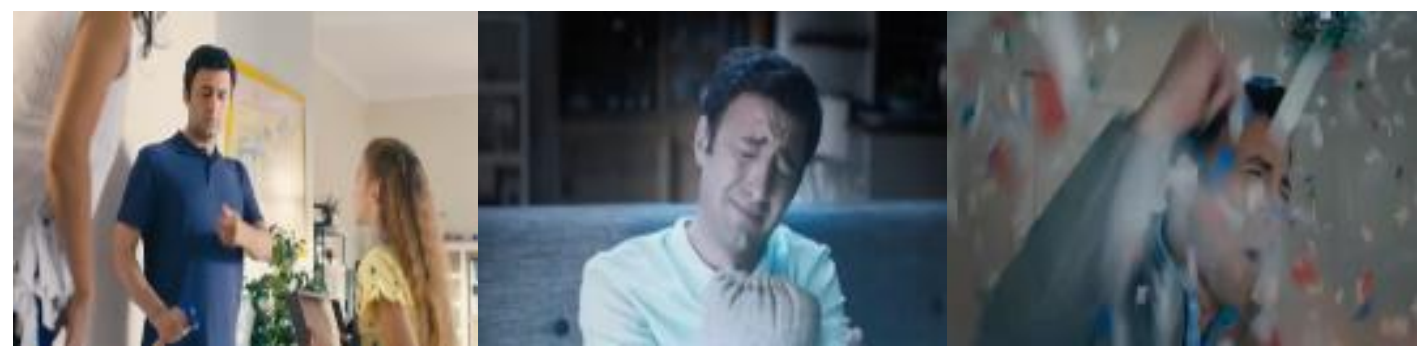

Yukarıdaki görsellerde görüldüğü gibi Kemal Tanca reklamında da "eline çivi ile vuran baba", "izlediği filmden etkilenip ağlayan baba", "kendisine yapılan sürpriz karşısında çok sevinen ancak belli etmeyen baba" gösterenleri ile "Babalar acı çekseler, üzülseler ya da çok sevinseler dahi duygularını göstermez kendi içlerinde yaşarlar." gönderileni çağrıştırılmakta, böylece babaların güçlü görünümlerinin ardında aslında duygusal bir taraf olduğu yan anlamı kurulmaktadır.

Opet reklamı baba rolüne farklı bir yorum getirerek kadın, erkek, genç, yaşlı fark etmeden babalığı yürekten hisseden herkesin babalar gününün kutlanması gerektiğine vurgu yapmıştır. Reklamda "gök gürülttüsünden korkan torununun başını okşayan dede", "evi taşırken ağır koliler kaldıran anne", "morali bozuk olan çırağı ile dertleşen usta" gösterenleri ile "Birine babalık yapmak için kan bağı olması gerekmez" gösterileni çağrıştırılmaktadır. Reklamda dilsel göstergelerle de babaların güçlü olduğuna, omuzlarında daima yük taşıdıklarına ve kahraman olduklarına" vurgu yapılmaktadır.
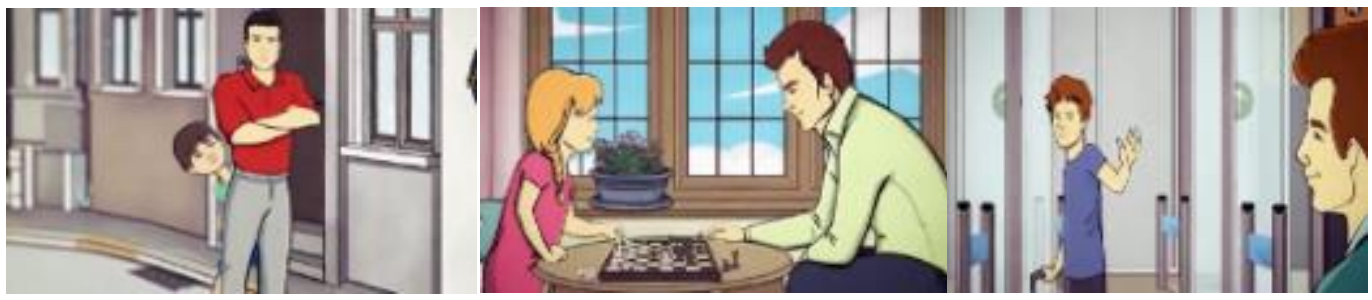

Turkish Studies, 15(2) 
Yukarıdaki görsellerde görüldüğü gibi Suvari reklamında "çocuğunu arkasında saklayan baba", "kızı ile satranç oynayan baba", "oğlunu yolcu eden baba" gösterenleri ile "babalar daima koruyan, kollayan, güven veren kişilerdir" anlamı kurulmaktadır. Bu anlamlar "en baba duruşuyla hep güven veren", "en baba zamanları birlikte geçirdiğimiz", "en baba tavrıyla her kararınızı destekleyen" dilsel göstergeleri ile de desteklenmektedir. Böylece "babalar çocuklarının gizli kahramanıdırlar" yan anlamı çağrıştırılmaktadır.

Toplumda cinsiyet açısından bakıldığında erkeklere daima güçlü, duygularını belli etmeyen bir kişi rolü yüklenmektedir. Babalar Günü reklamlarında da bu mit tekrarlanmakta, babanın güçlülüğüne, duygularını belli etmeyen yönüne vurgu yapılmaktadır.

\subsection{Baba Fedakârdır}

Baba fedakârdır teması altında 6 reklam incelenmiştir.

Tablo 6: Baba Fedakârdır Teması Altında Değerlendirilen Reklamlar

\begin{tabular}{|c|c|c|c|c|}
\hline Reklam & Gösteren & Gösterilen & Düz Anlam & Yan Anlam \\
\hline Corega & $\begin{array}{l}\text { Ağlayan torununu güldüren } \\
\text { dede }\end{array}$ & $\begin{array}{l}\text { Babalar sevgi } \\
\text { doludurlar. }\end{array}$ & $\begin{array}{l}\text { Babalar } \\
\text { sevgilerini } \\
\text { gösterirler. }\end{array}$ & $\begin{array}{l}\text { Babalar sevgi } \\
\text { doludur ve bu } \\
\text { sevgiyi daima } \\
\text { büyütürler. }\end{array}$ \\
\hline Garanti & $\begin{array}{l}\text { Kızı doğduğunda bıyı̆̆ını } \\
\text { kesen baba }\end{array}$ & $\begin{array}{l}\text { Babalar çocukları } \\
\text { için her şeyden } \\
\text { vazgeçebilirler. }\end{array}$ & $\begin{array}{l}\text { Babalar çocukları } \\
\text { için bıyıklarını } \\
\text { kesebilirler. }\end{array}$ & $\begin{array}{l}\text { Babalar } \\
\text { fedakârdırlar. }\end{array}$ \\
\hline İstikbal & $\begin{array}{l}\text { Babaların oturduğu } \\
\text { rahatsız koltuklar }\end{array}$ & $\begin{array}{l}\text { Babalar konforlu } \\
\text { olmayan } \\
\text { koşullarda } \\
\text { yaşayabilirler. }\end{array}$ & $\begin{array}{l}\text { Babaların okulda, } \\
\text { işte, parkta, } \\
\text { alışveriş merkezi } \\
\text { vb. oturdukları } \\
\text { koltuklar hep } \\
\text { rahatsızdır. }\end{array}$ & $\begin{array}{l}\text { Babalar rahat } \\
\text { etmeyi hak } \\
\text { ederler. }\end{array}$ \\
\hline Lassa & $\begin{array}{l}\text { Bilek güreşinde oğluna } \\
\text { yenilen baba, koşu } \\
\text { sırasında kızının kendisini } \\
\text { geçmesine izin veren baba, } \\
\text { çocuğu ile futbol oynarken } \\
\text { topun kaleye gitmesine izin } \\
\text { veren baba }\end{array}$ & $\begin{array}{l}\text { Babalar } \\
\text { çocuklarının } \\
\text { mutluluğu için } \\
\text { her şeyi yaparlar. }\end{array}$ & $\begin{array}{l}\text { Babalar çocukları } \\
\text { ile oyun } \\
\text { oynarken bilerek } \\
\text { yenilirler. }\end{array}$ & $\begin{array}{l}\text { Babalar } \\
\text { çocuklarının } \\
\text { mutluluğu için } \\
\text { daima fedakârlık } \\
\text { yaparlar. }\end{array}$ \\
\hline $\begin{array}{l}\text { Maximum } \\
\text { Kart }\end{array}$ & Jenerik müziği şarkı sözleri & $\begin{array}{l}\text { Babalar çocukları } \\
\text { için kendi } \\
\text { yorgunluklarını, } \\
\text { uykusuzluklarını } \\
\text { unutup fedakârlık } \\
\text { yaparlar. }\end{array}$ & $\begin{array}{l}\text { Babalar daima } \\
\text { çocuklarının } \\
\text { yanındadırlar. }\end{array}$ & $\begin{array}{l}\text { Babalar } \\
\text { fedakârdırlar. }\end{array}$ \\
\hline Vodafone & $\begin{array}{l}\text { Oğlunu kırmayıp } \\
\text { hastalığına rağmen trompet } \\
\text { çalan baba }\end{array}$ & $\begin{array}{l}\text { Babalar } \\
\text { kendilerinden } \\
\text { çok sevdiklerini } \\
\text { düşünürler. }\end{array}$ & $\begin{array}{l}\text { Babalar } \\
\text { sevdiklerinin } \\
\text { yanındadırlar. }\end{array}$ & $\begin{array}{l}\text { Babalar } \\
\text { sevdikleri için } \\
\text { daima fedakârlık } \\
\text { yaparlar. }\end{array}$ \\
\hline
\end{tabular}

"Baba fedakârdır" teması altında altı reklam incelenmiştir. Reklamlarda genel olarak kullanılan göstergeler ile babaların yaşadıkları tüm zorluklara rağmen sevdikleri için fedakârlık yaptıkları anlamı kurulmuştur.

Corega reklamında anneler günü reklamının tersine bu kez torununu güldüren kişi dededir. Bu gösteren ile "Babalar fedakâr ve sevgi doludur" gösterilenine gönderme yapılmaktadır. "Babalar sevgilerini gösterirler" düz anlamının gerisinde "babalar sevgi doludur ve bu sevgiyi daima 
büyütürler" yan anlamı bulunmaktadır. Bu yan anlam "sevgiyi büyütmek babalarımızla mümkün" dilsel göstergesi ile de desteklenmektedir.

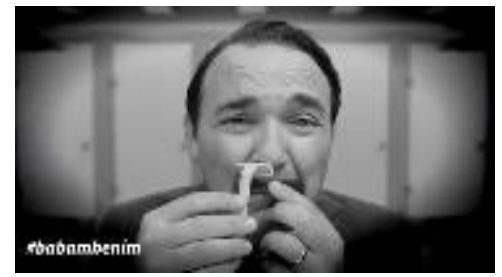

Yukarıdaki görselde görüldüğü gibi Garanti reklamında ise "Babalar fedakârdır" anlamı "kızı doğduğunda bıyığını kesen baba" göstereni ile kurulmaktadır. Bu anlam "Babaların çocukları için vaz geçemeyeceği hiçbir şey yoktur güzel kızım, bıyık ne ki!" dilsel göstergesi ile de desteklenmektedir. Böylece babalar çocukları için her şeyden vazgeçebilir vurgusu yapılarak babanın toplumsal rolü pekiştirilmektedir.

İstikbal reklamında babaların fedakârlığı diğer reklamlardan farklı bir yolla gösterilmeye çalışılmış, babaların okulda, maçta, parkta, alışveriş merkezinde eşlerini beklerken vb. yerlerde oturdukları koltukların görselleri kullanılmıştır.

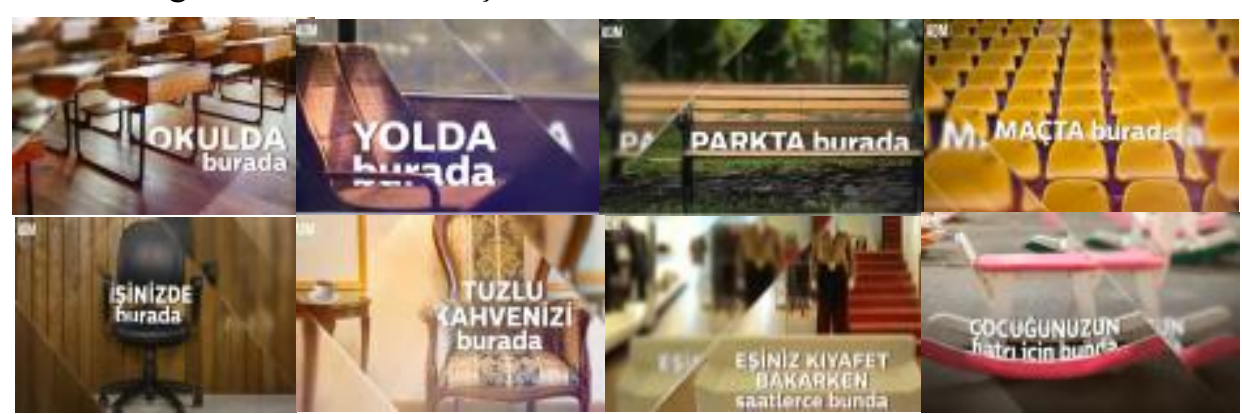

Yukarıdaki görsellerde de görüldüğ̈̈ gibi babaların oturdukları koltuklar hep rahatsızdır. Böylece babaların konforlu olmayan koşullarda bile hayatlarını sürdürebildikleri anlamı kurulmaktadır. Reklamın sonunda ise babalar günü hediyesi olarak TV koltuğu alınması önerisi yapılmaktadır. Görseldeki koltuk ise diğerlerine göre oldukça konforlu gözükmektedir. Böylece babaların yaşadıkları tüm zorluklardan sonra rahat etmeyi hak ettikleri vurgusu yapılmaktadır.

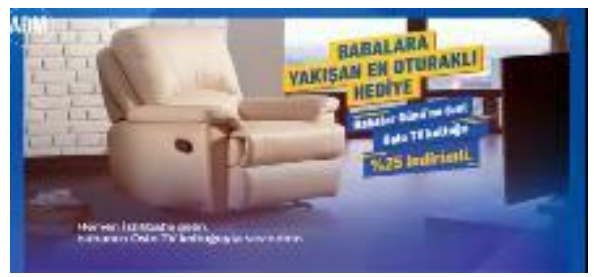

Burada dikkat çeken bir başka nokta ise babalara alınan hediyenin türüdür. Annelere Günü hediyesi olarak mutfak eşyası reklamı yapılırken (Arçelik reklamında olduğu gibi) Babalar Günü hediyesi olarak babaların kişisel kullanımına yönelik ve konforunu sağlayacak ürünlerin reklamı yapılmaktadır. $\mathrm{Bu}$ da toplumsal cinsiyet rolleri açısından anne ve baba rollerinin reklamlar aracılığıyla meşrulaştırılmasını beraberinde getirmektedir.

Lassa reklamında "Babalar çocuklarının mutluluğu için her şeyi yaparlar" gösterileni "bilek güreşinde oğluna yenilen baba", "koşu sırasında kızının kendisini geçmesine izin veren baba", "çocuğu ile futbol oynarken topun kaleye gitmesine izin veren baba" gösterenleri ile çağrıştırılmıştır.

Turkish Studies, 15(2) 


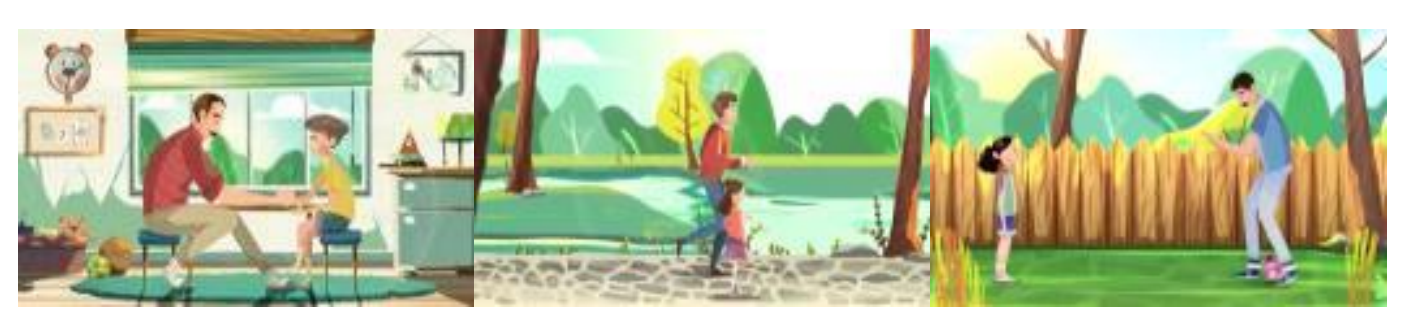

Reklamda babaların daima güçlü ve sağlam oldukları ancak çocukları söz konusu olduğunda onları mutlu etmek için yenilmeyi kabullendikleri belirtilerek, "babaların çocuklarına karşı daima fedakâr oldukları" anlamı kurulmaktadır.

Maximum Kart reklamında ise "babaların çocukları için yaptıkları fedakârlıklar reklam müziğindeki sözlerde kendini göstermektedir. "Eve yorgun dönsen de at olur, deh deh gidersin, hatta gezdirmek için uykundan vaz geçersin. Mangalda efsanesin, yemezsin yedirirsin. Hastayken gece boyu başucumda beni beklersin. Benim için neler yaptın, sevmeye doyamazsın. Canımdan daha yakınsın, iyi ki yanımdasın." şeklindeki sözlerde de dikkat çektiği gibi babaların tüm yorgunluklarına rağmen çocukları ile ilgilendikleri vurgusu yapılarak, "babalar fedakârdır" anlamı kurulmaktadır.

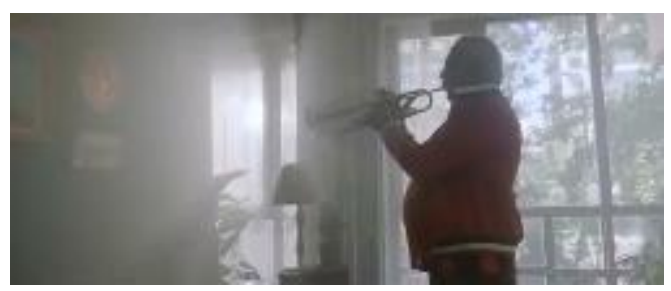

Yukarıdaki görselde görüldüğü gibi Vodafone reklamında ise "hastalığına rağmen oğlunu kırmayıp trompet çalan baba" göstereni ile "Babalar kendilerinden çok sevdiklerini düşünürler" anlamı çağrıştırılmakta ve "babalar fedakârdır" anlamı bu reklamda da kurulmaktadır.

Toplumsal cinsiyet rolleri açısından bakıldığında "Baba fedakârdır" teması altında değerlendirilen reklamlarda babaların evin geçimini sağlayan kişi olduğu anlamının kurulduğu dikkat çekmektedir. Ancak baba, evin geçimini sağlamak için ne kadar yorulsa da daima çocukları için fedakârlık yapar vurgusu yapılmaktadır. Dolayısıyla toplumsal cinsiyet rolleri açısından kadın evi çekip çeviren, erkek ise evin geçimini sağlayandır miti reklamlar aracıllğıyla yeniden üretilmektedir.

\section{Sonuç}

Anneler Günü ve Babalar Günü reklamlarında toplumsal cinsiyetin inşasına göstergebilimsel bir ayna tutmayı amaçlayan bu çalışmada, 2018 yılında, bu iki özel gün öncesinde ulusal televizyon kanallarında yayınlanan reklamlardaki toplumsal cinsiyetin kuruluşunda aktarılan mesajlar çözümlemeye tabi tutulmuştur. Anneler Günü ile ilgili toplam 21 reklam, Babalar Günü ilgili ile toplam 14 reklam incelenmiştir. İncelenen reklamların ortak temalar altında sinıflandırılması ile Anneler Günü reklamlarında "Anne güven verir", "Anne şefkatlidir", "Anne fedakârdır" temaları; Babalar Günü reklamlarında "Baba ilgili ama otoriterdir", "Baba güçlüdür, duygularını belli etmez" ve "Baba fedakârdır" temaları ortaya çıkmıştır.

Çalışmanın kuramsal bölümünde değinildiği gibi toplumsal cinsiyet, kadın ve erkeğin toplum içindeki konumunu belirlemektedir. Söz konusu bu konumlar toplumun büyük bir kısmı tarafından benimsenmiştir. Kadına, daha çok duygulu, sabırlı, becerikli, yumuşak başlı, sevgi dolu olma rolü verilirken; erkekten beklenen ise tersine cesur ve sert olması, sözünü dinletmesi, duyguları ile değil aklı ile hareket etmesidir. Kadından "iyi” annelik için beklenen evine, eşine, çocuklarına 
bağlılık ve fedakârlıktır. Erkekten "iyi" babalık için beklenen ise ailenin maddi ihtiyaçlarını karşılamak için dışarıda çalışması ve çok kazanmasıdır. Bir başka deyişle toplumsal cinsiyete dair rol kalıpları kadına evin içini, erkeğe ise evin dışını uygun görür. Zira kadın çalışıyor olsa bile yemek ve temizlik gibi ev içi sorumluluklar yine onun görevidir.

Çalışmada incelenen reklamlara bakıldığında toplumda kadın ve erkeğe atfedilen toplumsal cinsiyet rollerinin tekrarlandığı görülmektedir. Reklamlarda anne(kadın) sevgi dolu, güven veren, fedakâr, şefkatli olarak betimlenirken; baba (erkek) duygusallığını belli etmeyen, güçlü, evin geçimini sağlayan kişidir. İncelenen reklamlarda Anneler Günü reklamlarında annenin iş hayatına dair vurgu yapılmazken, Babalar Günü reklamlarında baba çalışan kişi olarak görülmektedir.

Ataerkil kapitalist sistem, kadının da iş hayatına girmesini ve emek gücünün bir parçası olmasını beraberinde getirmiştir. Ancak bu durum, kadınların doğal olarak ev mekânına ait varlıklar olarak görüldüğü gerçeğini değiştirmemiş, kadınlar ev içi yeniden üretim sistemlerinden sorumlu tutulmuştur. Dolayısıyla kadının emek piyasasında erkek iş gücüne ortak olması, toplumsal cinsiyet rolleri açısından bir fark yaratmamış, ev içi işler yine kadına atfedilmiştir. Kadınların kamusal alandaki çalışma eylemi gerçek bir iş gücü olarak görülmemekle birlikte babanın evin geçimini sağlayan kişi olma rolü geçerliliğini sürdürmektedir. İncelenen reklamlarda da anne daima ev içinde görülürken, baba dışarıda çalışan konumundadır. Anne çalışsa bile iş dışı zamanlarında evin işlerini yapan kişi olarak görülmektedir. Hem anne hem de babanın fedakârlığının altı çizilen reklamlarda annenin fedakârlığı çocuklarının iyiliği için kendi arzu ve isteklerinden vazgeçiş (Örneğin Çaykur reklamında çocukları için çayının içemeyen anne) olarak anlamlandırılmaktadır. Babaların fedakârlığı ise işten yorgun gelmesine rağmen dinlenmeden çocuklarının isteklerini yerine getirmesinde (Örneğin Maximum reklamında işten gelen babanın dinlenmeden çocuklarını gezmeye götürmesi) bulunmaktadır.

İncelenen reklamlarda annelere ve babalara alınan hediyelere ilişkin göstergelerin her reklamda olmadığı, Anneler Günü reklamlarından Arçelik, Babalar Günü reklamlarından ise Bonus ve İstikbal reklamlarında anne ve babalara alınabilecek hediyelerin ön plana çıkarıldığ belirlenmiştir. Anne ve babalara alınan hediyeler açısından bakıldığında da anne ve babanın toplumsal cinsiyet rollerinin reklamlara yansıdığını görmek mümkündür. Anneye küçük ev aleti, çiçek alınırken babaya kişisel kullanımı için koltuk alınmaktadır. Dolayısıyla hediye gösterenleri de anne ve babanın toplumsal rolüne gönderme yapmaktadır.

Toplumda babalar genellikle/geleneksel olarak çocukların bakımı ile ilgilenmez, bu görev anneye aittir. Babalar çocukları ile bireysel vakit geçirmezler, onlarla oyun oynamazlar, genellikle duygusal anlamda mesafeli olan ebeveynlerdir. Ancak incelenen reklamlarda babaya yüklenen bu rolün kırılmaya çalışıldığı görülmektedir. Babalar çocukları ile ilgilenen, onlara olan sevgilerini belli eden, çocukları ile kaliteli vakit geçiren bireyler olarak konumlandırılmışlardır.

Genel olarak söylemek gerekirse toplumda anne ve babaya atfedilen toplumsal cinsiyet rollerinin anneler günü ve babalar günü reklamlarında tekrarlandığı ve dolayısıyla söz konusu rollerin yeniden kurulduğunu söylemek mümkündür.

Yöntemin reklamlar arasındaki farkın nedenleri ve sonuçlarına dair derin ve kapsamlı bir yorum yapmaya yeterli ve elverişli olmayışı çalışmanın temel sınırlılıklardan biridir. Reklamcıların bakış açısını ve reklamların izleyiciler üzerindeki etkisini anlamak için farklı yöntemler ile çalışmalar yapılması da faydalı olacaktır.

\section{Kaynakça}

Alemdar, K., Erdoğan, İ. (1994). Popüler kültür ve iletişim. Ümit Yayıncılık. 
Allan, K., Coltrane, S. (1996). "Gender displaying television commercials: a comparative study of television commercials in the 1950s and 1980s." Sex Roles, 35(3/4): 185-203, https://doi.org/10.1007/bf01433106

Arendell, T. (2000). "Conceiving and investigating motherhood: the decade's scholarship." Journal of Marriage and the Family, 62:1192-1207, https://doi.org/10.1111/j.17413737.2000.01192.x

Ataman Yengin, D. (2012). "Mekanikleşen birey: Arçelik örneğinin R. Barthes'a göre çözümlenmesi." The Turkish Online Journal of Design, Art and Communication-TOJDAC, 2(1): 13-21, https://doi.org/10.7456/10201100/002

Auster, C., Auster-Gussman, L. (2016). “Contemporary Mother's Day and Father's Day greeting cards: a reflection of traditional 1deologies of motherhood and fatherhood?" Journal of Family Issues, 37(9): 1294-1326.

Barthes, R. (2016). S/Z (Çev.) Sündüz Öztürk Kasar. İstanbul: Sel Yayınları.

Baudrillard, J. (1997). Tüketim toplumu (Çev.) Hasan Deliçaylı ve Ferda Keskin. Ayrıntı Yayınları.

Baudrillard, J. (2004). Nesneler sistemi. Boğaziçi Üniversitesi Yayınları.

Bayhan, V. (2012). "Beden sosyolojisi ve toplumsal cinsiyet." Doğu Batı Düşünce Dergisi (Toplumsal Cinsiyet Özel Saylst), 16(63): 147-164, https://doi.org/10.17753/ekev1038

Belkaoui, A, Belkaoui, J. (1976). "A comparative analysis of the roles portrayed by women in print advertisements." Journal of Marketing Research, 13(2):168-172, https://doi.org/10.1177/002224377601300207

Bourse, M. ve Yücel H. (2012). İletişim bilimlerinin serüveni. Ayrıntı Yayınları.

Brandes, S. B. (2017). "Ideologies of motherhood in contemporary Israeli TV commercials, communication." Culture \& Critique, 10(1): 58-75, https://doi.org/10.1111/cccr.12143

Braun, V. and Clarke, V. (2006). "Using thematic analysis in psychology." Qualitative Research in Psychology, 3(2): 77-101.

Bretl, D. J., Cantor, J. (1988). "The portrayal of men and women in US television commercials: a recent content analysis and trends over 15 years." Sex Roles, 18 (9/10): 595-609, https://doi.org/10.1007/bf00287963

Butler, J. (2004). Undoing gender. Routledge.

Carter, C., Steiner, L. (2004). Critical readings: media and gender. Maidenhead, UK: Open University Press, Milton Keynes.

Cheng, H. (1997). "Holding up half of the sky? A sociocultural comparison of genderrole portrayals in Chinese and US advertising." International Journal of Advertising, 16(4): 295-319, https://doi.org/10.1080/02650487.1997.11104698

Coltrane, S., Adams, M. (2008). Gender and families. Rowman \& Littlefield.

Coltrane, S., Allan, K. (1994). "New fathers and old stereotypes: Represe ntations of masculinity in 1980 television advertising." Masculinities, 2: 43- 66.

Cote, N., Deutsch, F. (2008) Flowers for mom, a tie for dad: How gender is created on Mother's and Father's Day. Gender Issues, 25: 215-228, https://doi.org/10.1007/s12147-008-9066-4 
Courtney, A., Lockeretz, S. W. (1971). "A woman's place: an analysis of the roles portrayed by women in magazine advertisements." Journal of Marketing Research, 8(1): 92-95, https://doi.org/10.1177/002224377100800114

Craig, S. (1992). "The effect of television day parts on gender portrayals in television commercials: A content analysis." Sex Roles, 26: 197-211, https://doi.org/10.1007/bf00289707

Crosby, C. (1992). "Dealing with differences." Feminists Theorize the Political. (Ed.) Judith Butler and Joan Scott. 130-143. Routledge.

Çağl1, U., Durukan, L. (1989). "Sex role portrayals in Turkish television advertising: Some preliminary findings." METU Studies in Development, 16: 153-175.

Çamdereli, M. (2006). Reklam arası. Konya: Tablet Yayınları.

Çankaya, M. (2013). "Traditional? modern? or both? representation of gender in Turkish TV commercials." SDÜ Fen Edebiyat Fakültesi Sosyal Bilimler Dergisi, 30: 279-295.

Çelenk, S. (2005). Televizyon temsil kültür. Ütopya Yayınları.

Dağtaş, B. (2013). "Dilbilimsel ve göstergebilimsel yaklaşım”. İletişim Kuramları. (Der.) Erkan Yüksel Anadolu Üniversitesi Yayınları. 132-155.

Davidson, M. (1992). The consumerist manifesto advertising in postmodern times. Routledge.

Deaux, K., Lewis, L.L. (1984). "Structure of gender stereotypes: Interrelationships among components and gender label." Journal of Personality and Social Phychology, 46: 991-1004, https://doi.org/10.1037/0022-3514.46.5.991

Dyer, G. (2010). Illetişim olarak reklamcılık. (Çev.) M. Nurdan Öncel Taşkıran. Beta Basım A.Ş.

Eisend, M. (2010). "A meta-analysis of gender roles in advertising." Journal of the Academy of Marketing Science, 38: 418-440.

Elden, M. (2016). Reklam yazarlı̆̆ı. İletişim Yayınları.

Erdoğan, İ. (2002). Illetişimi Anlamak. Erk Yayınları.

Eziler Kıran, A. (2000). "Reklamlar ve kadın.” Gazi İletişim Dergisi, 6: 8-17.

Feasey, R. (2008). Masculinity and Popular Television. Edinburgh University Press.

Fereday, J. and Muir-Cochrane, E. (2006). "Demonstrating rigor using thematic analysis: a hybrid approach of inductive and deductive coding and theme development." International Journal of Qualitative Methods, 5(1): 1-11, https://doi.org/10.1177/160940690600500107

Fiske, J. (2011). İletişim çalışmalarına giriş. (Çev.) Süleyman İrvan. Pharmakon Yayıncılık.

Furnham, A., Babitzkow, M., Uguccioni, S. (2000). "Gender stereotyping in television advertisements: a study of French and Danish television." Genetic Social and Psychology Monographs, 126(1): 79-104.

Furnham, A., Imadzu, E. (2002). "Gender portrayal in British and Japanese TV advertisements." Communications, 27(3): 319-348, https://doi.org/10.1515/comm.27.3.319

Furnham, A., Mak, T. (1999). "Sex-role stereotyping in television commercials: a review and comparison of fourteen studies done on five continents over 25 years." Sex Roles, 41 (5/6): 413-37. 
Furnham, A., Skae, E. (1997). "Changes in the stereotypical portrayal of men and women in British television advertisements." European Psychologist, 2(1): 44-51, https://doi.org/10.1027/1016-9040.2.1.44

Ganahl, D., Prinsen, T., Netzley, S. B. (2003). "A content analysis of prime-time commercials: A contextual framework of gender representation." Sex Roles, 49: 545-551.

Geray, H. (2017). Toplumsal araştırmalarda nicel ve nitel yöntemlere giriş. Ütopya Yayınevi.

Giddens, A. (2012). Sosyoloji. (Çev.) İsmail Yılmaz. Kırmızı Yayınları.

Gilly, M. C. (1988). "Sex roles in advertising: a comparison of television advertisements in Australia, Mexico and the United States." Journal of Marketing, 52(1): 75-85, https://doi.org/10.1177/002224298805200206

Goffman, E. (1987). Gender Advertisements. Harper Torchbooks.

Green, F. J. (2004). "Feminist mothers: Successfully negotiating the tension between motherhood as an "institution" and "experience." From Motherhood to Mothering. (Ed.) Andrea O'Reilly. Suny Press. 125-136.

Günindi Ersöz, A. (2016). Toplumsal cinsiyet sosyolojisi. Anı Yayıncılık.

Holmes, C. (2006). Born to doitt? The social construction of motherhood. Unpublished Master Thesis Simon Fraser University, Department of Women Studies, Canada.

Htun, M., Weldon, L. (2018). The logics of gender justice: state action on women's rights around the World. Cambridge University Press.

İmançer, D., Özel, Z. (1999). "Göstergebilimsel Çözümleme- Örnek Çözümleme: Pirelli Reklamı.” Sinemasal Dergisi. Bahar. 7-20.

Jha Dang, P., Vohra, N. (2005). "Role portrayals of men and women in Indian television advertising." Abhigyan, 23(1): 36-44.

Johnston, D. D., Swanson, D. H. (2003). "Undermining mothers: A content analysis of the representation of mothers in magazines." Mass Communication and Society, 6(3): 243-265, https://doi.org/10.1207/s15327825mcs0603_2

Jones, K. W. (1980). "Mother's day: The creation, promotion and meaning of a new holiday in the progressive era." Studies in Literature and Language, 22(2): 175-196, https://doi.org/10.1515/9783110971095.503

Kim, K., Lowry, D. N. (2005). "Television commercials as a lagging social indicator: Gender role stereotypes in Korean television advertising." Sex Roles, 53: 901-910, https://doi.org/10.1007/s11199-005-8307-1

Kuruoğlu, B., Aydın, B. (2014). Toplumsal cinsiyet ve medya. Detay Yayıncılık.

LaRossa, R. (1997). The modernization of fatherhood: A social and political history. University of Chicago Press.

Lovdal, L. (1989). "Gender role messages in television commercials: An update." Sex Roles, 21: 715-724, https://doi.org/10.1007/bf00289804

Lyons, A. and Rohleder, P (2015). Qualitative research incClinical and health psychology. Palgrave Macmillan.

Macionis, J. (2013). Sosyoloji. (Çev.) Vildan Akan. Nobel Yayınları.

Marks, D. and Yardley, L. (2004). Research methods for clinical and health psychology. Sage. 
Marsiglio, W., Amato, P., Day, R. D., Lamb, M. E. (2000). "Scholarship on fatherhood in the 1990s and beyond." Journal of Marriage and the Family, 62: 1172-1191, https://doi.org/10.1111/j.1741-3737.2000.01173.x

Miller, T. (2011). Making sense of fatherhood. Cambridge University Press.

Morman, M., Floyd, K. (2006). "Good fathering: Father and son perceptions of what it means to be a good father." Fathering, 4(2): 113-136, https://doi.org/10.3149/fth.0402.113

Nicholson, L. (1994). “Interpreting Gender.” Signs, 20(1): 79-105.

Odabaşı, Y. (2005). Pazarlama iletişim yönetimi. MediaCat Yayınları.

Özdemir, M. (2010). "Türkiye'deki reklamlarda toplumsal cinsiyet ve sunumu." Milli Folklor, 22(88): 101-111.

Paek, H., Nelson, M. R., Vilela, A. M. (2010). "Examination of gender-role portrayals in television advertising across seven countries." Sex Roles, 64: 192-207, https://doi.org/10.1007/s11199010-9850-y

Peltekoğlu, F. (2018). Halkla ilişkiler nedir? Beta Basım Yayım.

Perkins, T. (1997). "Rethinking stereotypes.” The Media Studies Reader. (Ed.) Tim O'Sullivan and Yvonne Jewkes. Arrowsmith. 75-85.

Prinsloo, J. (2006). "Where have all the fathers gone? Media(ted) representations of fatherhood." Baba: Men and Fatherhood in South Africa. (Ed.) Lind Richter and Robert Morrell. Human Sciences Research Council. 132-146.

Quelter, T. H. (1991). Advertising and democracy in the mass age. Mac Millan.

Ridgeway, C. L. (2011). Framed by gender: How gender inequality persists in the modern world. Oxford.

Sancar, S. (2009). Erkeklik: imkânsız iktidar/ ailede, piyasada ve sokakta erkekler. Metis Yayınları.

Sengupta, S. (1995). "The influence of culture on portrayals of women in television commercials: acomparison between the United States and Japan.” International Journal of Advertising, 14(4): 314-333, https://doi.org/10.1080/02650487.1995.11104622

Sezer, N. ve Yılmaz Sert, N. (2014). "TV kamu spotu reklamlarının medya okuryazarlı̆g 1 çerçevesinde kullanılması: 'çocuk ve medya hareketi' TV kamu spotu reklamının göstergebilimsel çözümlemesi” İletişim Araştırmalarında Göstergebilim. (Der.) Ahmet Güneş. Literatürk Yayınları.

Shaw, S., Lee, J. (2009). Women's voices, feminist visions. McGraw-Hill.

Sherry, J. F. (1987). "Advertising as a Cultural System." (Ed.) J. Umiker Sebeok. Mounton de Gruyter. 441-458.

Simons, L. and Lachlean, J., Squire, C. (2008). "Shifting the focus: sequential methods of analysis with qualitative data." Qualitative Health Research, 18: 120-132, https://doi.org/10.1177/1049732307310264

Stern, B. (2003). "Masculism(s) and the male image: What does it mean to be a man?" Sex in Advertising: Perspectives on the Erotic Appeal. (Ed.) Tom Reichert and Jacqueline Lambiase. Lawrence Erlbaum. 215-228.

Stewart, L., Cooper, P., Stewart, A., Friedley, S. (2002). Communication and gender. Pearson. 
Taylor, S. J. and Bogdan, R. C. (1989). Introduction to Qualitative Research Methods: The Search for Meanings. John Wiley \& Sons.

Toruk, İ., Güran, S., \& Sine, R. (2013). "Boş zaman aktivitelerinin toplumsal cinsiyet ekseninde medyada temsili." Selçuk Üniversitesi Türkiyat Araştırmaları Dergisi, 33: 301-324, https://doi.org/10.21563/sutad.187062

Tosun, N. B. (2006. "Reklam aracı olarak kadın.” Kadın Çalışmaları Dergisi, 1(1): 88-93.

Uray, N., Burnaz, Ş. (2003). "An Analysis of the Portrayal of Gender Roles in Turkish Television Advertisements.” Sex Roles, 48(1/2): 77-87, https://doi.org/10.1023/a:1022348813469

Ünsal, İ. (1984). Bilimsel reklam ve pazarlamadaki yeri. Tivi Reklam.

Warner, J. (2005). Perfect madness: Motherhood in the age of anxiety. Riverhead.

Wernick, A. (1996). Promosyon kültürü-reklam, ideoloji ve sembolik anlatım. (Çev.) Osman Akınhay. Bilim ve Sanat yayınları.

West, E. (2009). "Doing gender difference through greeting cards: The construction of a communication gap in marketing and everyday practice." Feminist Media Studies, 9: 285299, https://doi.org/10.1080/14680770903068241

Whipple, T., Courtney, A. (1985). "Female role portrayals in advertising and communication effectiveness: a review." Journal of Advertising, 14(3): 4-17, https://doi.org/10.1080/00913367.1985.10672951

Wiles, C.R. \& Tjernlund, A. (1991). "A comparison of role portrayal of men and women in magazine advertising in the USA and Sweden." International Journal of Advertising, 10(3): 259-267, https://doi.org/10.1080/02650487.1991.11104457

Wood, J. T. (2009). Gendered lives-communication, gender, and culture. Wadsworth Cengage Learning.

Yapar, A. (1999). "Kadın dergilerinde kadın imgesinin kullanımı." İstanbul Üniversitesi İletişim Fakültesi Dergisi, 9: 75-80.

Yıldırım, A. ve Şimşek, H. (1999). Sosyal bilimlerde nitel araştırma yöntemleri. Seçkin Yayınları.

Yılmaz, A. (2007). "Reklamlarda toplumsal cinsiyet kavramı: 1960-1990 y1lları aras1 Milliyet gazetesi reklamlarına yönelik bir içerik analizi." Selçuk İletişim, 4(4): 143-156. 